\title{
Expedition 343/343T summary ${ }^{1}$
}

\author{
Expedition 343/343T Scientists ${ }^{2}$
}

\section{Chapter contents}

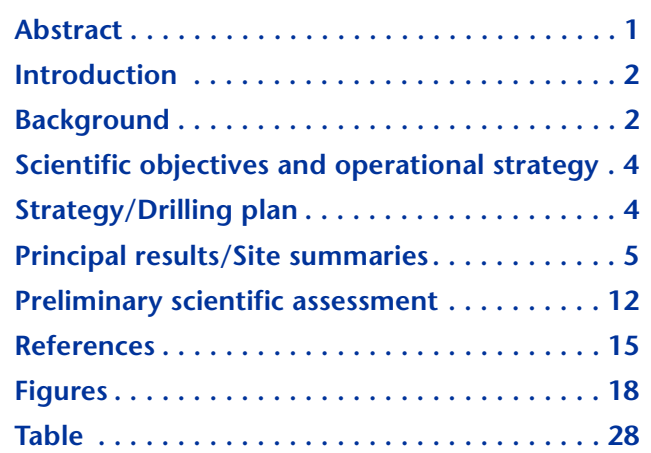

${ }^{1}$ Expedition 343/343T Scientists, 2013. Expedition 343/343T summary. In Chester, F.M., Mori, J., Eguchi, N., Toczko, S., and the Expedition 343/ 343T Scientists, Proc. IODP, 343/343T: Tokyo (Integrated Ocean Drilling Program Management International, Inc.).

doi:10.2204/iodp.proc.343343T.101.2013

2Expedition 343/343T Scientists' addresses.

\section{Abstract}

The main science goal of the Japan Trench Fast Drilling Project (JFAST) is to understand the physical mechanisms and dynamics of large slip earthquakes, which is fundamental to understanding the huge tsunami that caused extensive damage during the 2011 Tohoku-oki earthquake. Specifically, the level of frictional stress during the earthquake rupture and the physical characteristics of the fault zone are investigated through drilling. The objectives of JFAST include locating the fault that ruptured during the Tohokuoki event using logging while drilling (LWD); characterizing the composition, architecture, and fundamental mechanisms of dynamic frictional slip and healing processes along the fault by taking core samples; and estimating the frictional heat and stress within and around the fault zone by placing a temperature measurement observatory across the fault.

During the main JFAST expedition (Integrated Ocean Drilling Program [IODP] Expedition 343 in April and May 2012), LWD was completed in a borehole drilled to 850.5 meters below seafloor (mbsf) (total depth $[\mathrm{TD}]=7740$ meters below sea level [mbsl]), and a coring hole was drilled to $844.5 \mathrm{mbsf}$ ( $\mathrm{TD}=7734 \mathrm{mbsl}$ ) to acquire 21 cores that spanned the two main fault targets. Because of delays associated with severe weather and technical challenges of operating in great water depths, installation of the observatory for temperature and pressure measurements was not completed during the main expedition. However, temperature sensors were successfully deployed during a short technical extension of JFAST, IODP Expedition 343T, in July 2012.

Principal results of Expedition 343/343T include the following:

1. The overall structure at the drill site consists of a prism of faulted and folded clayey to silty mudstones above and in fault contact (at $\sim 820$ mbsf) with a largely undeformed, relatively thin sequence of hemipelagic and pelagic sediments that were deposited on top of the incoming Pacific plate. The primary constituents of the mudstones that make up the prism are terrigenous silt and clay, vitric ash, and biogenic silica. The fault contact, interpreted as the plate boundary décollement, is defined by a subhorizontal, $<5 \mathrm{~m}$ thick zone of highly sheared clay that displays penetrative scaly fabric and localized slip surfaces. 
2. Faults and bedding are variable in dip magnitude, but faults and bedding at all depths in the prism show a preferred northeast strike direction reflecting horizontal contraction and local extension (at shallower depths) approximately parallel to the plate convergence direction.

3. Borehole breakouts are evident in image logs from the LWD hole and indicate several different in situ stress domains along the borehole. At shallow depths (from $<200$ to $\sim 500 \mathrm{mbsf}$ ), the maximum horizontal compressive stress $\left(S_{\text {Hmax }}\right)$ is variable and shows a complicated pattern. At deeper levels in the prism (537-820 mbsf), $S_{\text {Hmax }}$ displays a single preferred orientation $\sim 20^{\circ}$ clockwise from the plate convergence direction.

4. Fault slip during the 2011 event and other past earthquakes likely occurred on the plate boundary décollement. However, slip on other faults cutting the prism could have also occurred during the Tohoku-oki event. One possible location of recent fault slip is identified at $~ 700$ mbsf on the basis of a local $\mathrm{H}_{2}$, methane, and chlorinity anomaly. Several core samples from a fractured and brecciated zone at $\sim 720$ mbsf contain faults, the largest of which is a high-angle reverse fault that occurs at the same depth as a low-resistivity feature identified in image logs. The fault at $\sim 720$ mbsf and the décollement at $\sim 820$ mbsf are the two primary targets for the temperature measurement observatory.

5. Successful recovery of $\sim 1 \mathrm{~m}$ of highly sheared clay from the plate boundary décollement and of the neighboring sediments provide material for mechanical and physical properties testing, as well as for geochemical, mineralogical, and microstructural analyses. Four special interest structural whole-round samples taken from the sheared clay of the décollement, as well as three other structural whole rounds capturing secondary faults, will provide material for coordinated nondestructive and destructive investigations of structure, chemistry, and mineralogy of the faulted sediments.

6. An observatory consisting of 55 temperature sensors and autonomous data loggers was successfully installed across the two fault targets. These instruments are monitoring temperature distribution across the lower portion of the borehole to estimate the amount of frictional heat dissipated along the slip zone of the Tohoku-oki earthquake in order to estimate the level of dynamic frictional strength during the earthquake. The temperature data loggers are scheduled to be retrieved in February 2013.

\section{Introduction}

The 2011 Tohoku-oki earthquake (Mw 9.0) and accompanying tsunami devastated much of the northeast coast of Honshu, Japan, and highlighted many of the poorly understood aspects of how great earthquakes occur. An important aspect of the event was the very large amount of slip $(\sim 50 \mathrm{~m})$ on the shallow portion of the megathrust, which is the largest displacement ever recorded in an earthquake (Fujiwara et al., 2011; Ito et al., 2011; Sato et al., 2011). Based on current ideas of the rheology and behavior of shallow faults, the large amount of displacement and its location, which reached the trench, was not anticipated (Ammon et al., 2011; Avouac, 2011; Ide et al., 2011). The huge amount of movement on the shallow portion of the megathrust and associated displacement of the ocean floor was the main cause of the destructive tsunami (Ito et al., 2011; Ide et al., 2011; Fujii et al., 2011).

The scientific community needs to learn as much as possible from this extreme event. Specifically, we want to clarify the physical conditions and state of stress that enabled the large slip to occur. We also hope to identify the effects of the earthquake on the fault zone so that we can identify the recent event and other events in the geological record. With understanding of the physical conditions on the fault zone and knowledge of past earthquakes, we will be able to improve evaluations of future occurrences of large tsunamis in the Tohoku region, as well as for other subduction zones around the world (e.g., Ozawa et al., 2011; Ammon et al., 2011).

An important aspect of Integrated Ocean Drilling Program (IODP) Expedition 343 (Japan Trench Fast Drilling Project [JFAST]) is the priority on collecting time-dependent observations of fault properties following a large earthquake. Measurements of the decaying temperature of the fault zone, as well as analyses of the changing stress and chemical properties of the fault rocks, are important observations that need to be made soon after the earthquake (Brodsky et al., 2009; Fulton et al., 2010). The sailing of this expedition within 13 months following the earthquake reflects the rapid response taken by IODP to provide scientific information about large-scale geohazards that severely impact our societies.

\section{Background Geological setting}

The 2011 Tohoku-oki earthquake occurred on the megathrust fault surface west of the Japan Trench 
where the Pacific plate of Cretaceous age subducts below Honshu Island (Fig. F1). The subduction zone is characterized by a relatively rapid convergence rate of $\sim 83 \mathrm{~mm} / \mathrm{y}$ (e.g., Apel et al., 2006; DeMets et al., 2010; Argus et al., 2011), a high rate of seismic activity, and a deep trench (Kanamori et al., 2006; Hashimoto et al., 2009; Simons et al., 2011). The historical record for the region includes some thirteen Mw 7 and five Mw 8 earthquakes over the last 400 years. The convergent margin of the Japan Trench displays the features generally associated with subduction erosion (von Huene et al., 1994, 2004; Tsuru et al., 2000), specifically, evidence of subsidence in the Neogene with associated extensional faulting in the middle slope region, horst and graben structures in the upper portion of the subducting plate, and a relatively small frontal prism $(5-15 \mathrm{~km}$ wide) containing landward-dipping reflectors and a backstop bounding the frontal prism on the landward side.

The structure and lithology of the forearc region of northern Japan were investigated during Deep Sea Drilling Project (DSDP) Legs 56 and 57 (Arthur and Adelseck, 1980), and later observatories were established in the forearc during Ocean Drilling Program (ODP) Leg 186 (Sacks, Suyehiro, Acton, et al., 2000). ODP Leg 186 Sites 1150 and 1151 are located above the region of large fault slip during the Tohoku-oki earthquake, $\sim 100 \mathrm{~km}$ north of the epicenter (e.g., Lin et al., 2011). DSDP Leg 56 and 57 Sites 434-441 are located $\sim 50-100 \mathrm{~km}$ further north (Fig. F1). In this region, the Japan Trench system consists of a deepsea terrace, inner trench slope, midslope terrace, trench lower slope, trench, and outer trench slope (Arthur and Adelseck 1980; Tsuru et al., 2002). A forearc basin formed at the deep-sea terrace contains sequences of Neogene sediments as thick as $5 \mathrm{~km}$ overlying a Cretaceous unconformity, which correlates with a regional unconformity and relates to geologic features on land. The overlying sediments extend trenchward through the midslope terrace to the backstop boundary, and the frontal prism forms the trench lower slope (e.g., Tsuru et al., 2000). Seismic profiling indicates the structure in the northern Japan Trench is similar through the region to the south that ruptured during the Tohoku-oki event (Tsuru et al., 2002).

The frontal prism is characterized by lower seismic velocity than the region landward of the backstop, and the prism displays disrupted-to-chaotic reflection patterns that likely indicate strong deformation (e.g., Tsuru et al., 2000). Coring of the toe region of the frontal prism at Site 434 revealed the prism is composed of a highly disrupted, very uniform hemipelagic deposit (Shipboard Scientific Party, 1980a).
The major constituents are terrigenous silty clay, biogenic silica, and vitric ash. Biostratigraphic observations indicate structural complexity in the prism with repetition of assemblages that could record slumping, sliding, and faulting. Significant induration of the sediments occurs at depths below $\sim 100 \mathrm{~m}$, and the mudstones recovered are highly fractured with slickensided faces. The highly fractured and disrupted structure contributed to the difficulties of coring and poor core recovery at Site 434 .

\section{Seismic studies/Site survey}

The offshore Tohoku region is well characterized from decades of data collection, including some high-resolution surveys of bathymetric and seismic reflection data taken after the 2011 Tohoku-oki earthquake (Kodaira et al., 2012; Fujiwara et al., 2011). A differential bathymetry analysis across the trench axis eastward of the hypocentral area, using data collected along the same track before and after the earthquake, shows large topographical changes on the landward side of the trench. From analysis of differential bathymetry, Fujiwara et al. (2011) demonstrate $\sim 50 \mathrm{~m}$ of horizontal movement toward the southeast and 7-10 $\mathrm{m}$ of upward movement during the earthquake. In addition, a large submarine landslide scarp on the lower trench wall and associated slump deposits in the trench are indicated by the distinct negative and positive seafloor elevation changes at the trench. A critical result is that the coseismic displacement of the 2011 Tohoku-oki earthquake extended all the way to the landslide scarp, if not to the trench axis proper (Kodaira et al., 2012). The pervasive and similar magnitude of displacement along the profile shows that the frontal prism was displaced as a coherent unit along a fairly uniform dipping detachment surface. Analysis of other data sets also points to coseismic slip on the order of $50 \mathrm{~m}$ that extends to the trench (e.g., Ito et al., 2011; Ide et al., 2011; Simons et al., 2011; Fujii et al., 2011).

Based on the above observations and the geometric continuity with the deeper main detachment surface, the plate interface is considered to be the most likely fault surface of large displacement during the earthquake (e.g., Ito et al., 2011; Kodaira et al., 2012).

The Japan Agency for Marine-Earth Science and Technology (JAMSTEC) carried out high-resolution seismic surveys in the area of the large seafloor displacement. Multichannel seismic data perpendicular to the trench axis along Line HD33B (Fig. F1) show a strong reflector at $\sim 800$ meters below seafloor (mbsf) that is thought to be the sediment/basalt interface of 
the subducting Pacific plate (Fig. F2). A weak reflector $\sim 50 \mathrm{~m}$ above this strong reflector is interpreted as the megathrust fault zone and is the main target of JFAST drilling.

The selection of the drilling site was constrained by a maximum penetration depth of 1000 mbsf for riserless drilling and a maximum water depth of $7000 \mathrm{~m}$. The plate interface shallows toward the trench but the water deepens. Generally, the plate interface at a water depth of $\sim 7000 \mathrm{~m}$ is shallower near $38^{\circ} \mathrm{N}$ and deeper further north. On the basis of existing seismic data, the primary site was identified as a location that minimizes both water depth and fault depth below the seafloor (Fig. F3).

\section{Scientific objectives and operational strategy}

The main goal of Expedition 343 is to understand the stress conditions and physical characteristics of the fault that allow very large slip to occur near the trench. The following specific science objectives reflect the unique possibilities provided by rapid response drilling into a fault following a large earthquake. The shallow distribution of large slip for the Tohoku-oki earthquake provides an unprecedented opportunity to directly access a fault that has recently moved tens of meters. As outlined in the report from the International Continental Scientific Drilling Program/Southern California Earthquake Center international workshop on rapid response drilling (Brodsky et al., 2009), fundamental questions regarding stress, faulting-related fluid flow, and the structural and mechanical characteristics of the earthquake rupture zone can be addressed uniquely through rapid response drilling.

The science questions and strategies for addressing them are as follows:

1. What was the stress state on the fault that controls rupture during the earthquake, and was the shear stress on the fault completely released?

- Dynamic friction during the rupture: potentially the most significant result of this project will be determining a value for the dynamic frictional stress. Measurements of the time-decaying temperature will be used to estimate the frictional heat produced at the time of the earthquake, which can be used to infer the level of dynamic frictional stress.

- Rupture to the toe of the sedimentary wedge: past thinking was that sediments in this region are weak and rate strengthening, so earthquake instability should not nucleate or easily propagate through this region. Measurements of current stress and stress during the earthquake can be used to explore different models to explain how dynamic slip occurred. Hydrogeological measurements can also help constrain the healing process of the fault.

2. What are the characteristics of large earthquakes in the fault zone, and how can we distinguish recent and geologic past events in the fault zone?

- Core analyses: detailed studies of textures and small-scale structures of core samples from the fault zone will be used to infer the role of fluids and pressurization during rupture. We will look for evidence of melting or other processes that contribute to dynamic strength reduction. Trace element chemistry and other physical and geochemical anomalies will be used to estimate the thermal history of the recent and past events.

- Laboratory experiments: high-speed friction and petrophysical experiments on fault material can be used to characterize the frictional behavior of the fault.

Secondary science objectives include carrying out other geological, geochemical, and microbiological observations to the greatest extent possible during drilling in accordance with the IODP Measurements guidelines (www.iodp.org/program-policies/). As a specific example, there is some evidence that great amounts of hydrogen may be released at the time of large faulting (e.g., Kita et al., 1982). The production of hydrogen may stimulate microbiological activity; thus, samples of the fault may contain records of biogeochemical and microbiological processes.

The primary science objectives are closely aligned with the Initiative: Seismogenic Zone of the IODP Initial Science Plan. This initiative advocates subduction zone studies that include investigating the behavior of rocks and sediments to better understand the fault zone and integration with studies of earthquake mechanics. Furthermore, this project directly addresses Challenge 12 of the IODP Science Plan for 2013-2023: "What mechanisms control the occurrence of destructive earthquakes, landslides, and tsunami?"

\section{Strategy/Drilling plan}

Details regarding the original drilling plan are available in Mori et al. (2012), but the general planned sequence of drilling was as follows:

1. Drilling the pilot hole with logging while drilling (LWD)/measurement while drilling (MWD) to total depth (TD), planned for $~ 900 \mathrm{mbsf}$; 
2. Running casing and a completion assembly (including long-term temperature monitoring with a string of autonomous data loggers) in the LWD/MWD hole to $\sim 900 \mathrm{mbsf}$ (casing to $50 \mathrm{~m}$ below fault, $\sim 900 \mathrm{~m}$ );

3. Drilling a second hole with the rotary core barrel (RCB) and center bit to $\sim 500$ mbsf and continuation with RCB coring to $\sim 900$ mbsf; and

4. Running casing and a completion assembly for the second hole (including long-term temperature and pressure monitoring with the telemetered sensor string) to $\sim 900 \mathrm{mbsf}$ (casing to $50 \mathrm{~m}$ below fault, $\sim 900 \mathrm{~m}$ ).

\section{Principal results/Site summaries}

Although severe weather and failure of various equipment delayed operations at Site C0019, nothing occurred that would have required abandonment of the primary goals of the expedition and shifting to contingency sites. Accordingly, all drilling and coring activities occurred at IODP Site C0019 (Fig. F3) for the duration of the expedition. During JFAST (Expedition 343) in April and May 2012, the LWD/MWD pilot hole (C0019B) was drilled to a TD of 850.5 mbsf (Fig. F4). In preparation for later deployment of the autonomous temperature measurement observatory, a wellhead and 20 inch casing were successfully set in Hole C0019D. Finally, the coring hole was successfully completed in Hole C0019E, where spot cores were acquired from various depths to the TD of 844.5 mbsf. The LWD/MWD and coring holes were blind-spudded with an estimated $5 \mathrm{~m}$ of separation at the seafloor. During IODP Expedition 343T in July 2012, the wellhead in Hole C0019D was successfully reentered to extend the borehole to a TD of $854.8 \mathrm{mbsf}$ (Fig. F4). Subsequently, the $4 \frac{1}{2} 2$ inch casing containing the miniature temperature logger (MTL) autonomous observatory was installed and the observatory was completed (Table T1).

\section{Site C0019}

\section{Geophysical logging}

Hole C0019B was drilled to 850.5 mbsf, and the entire hole was successfully logged using a LWD/MWD assembly. The logging tools used during Expedition 343 include two of Schlumberger's VISION series tools, namely geoVISION and arcVISION, in addition to their MWD TeleScope tool. Four log-based units were defined on the variability of log responses (Fig. F5). In the upper $800 \mathrm{~m}$ of the borehole, in log Units I and II, the overall responses of both gamma ray and resistivity increase with depth. In the gamma ray $\log$, this trend is broken by significant low values that occur at 168 and 535 mbsf. There is some evidence of cyclicity in the resistivity log response, and the resistivity-at-the-bit (RAB) images also show multiple zones transitioning from darker, more conductive layers to lighter, more resistive bands with depth. Similarly, the abundance of borehole breakouts is variable, with low occurrences below 230, 470, and 730 mbsf. The patterns described above could infer sediment packages of different lithologies, an overall homogeneous sediment unit cut by thrust faults (producing repeated sediment packages), or a combination of these. The gamma ray and resistivity $\log$ responses from the upper $800 \mathrm{~m}$ of Hole C0019B compare favorably to those of diatomaceous muds that were recovered and logged at neighboring ODP Sites 1150 and $1151 \sim 100 \mathrm{~km}$ away (Sacks, Suyehiro, Acton, et al., 2000) and at DSDP Sites 436 and 434 (Shipboard Scientific Party, 1980a, 1980b).

Log Unit III (820.6-835.9 mbsf) is defined by a significant increase in gamma ray intensity relative to the units above and remains high for $16 \mathrm{~m}$ before dropping sharply (Fig. F5). RAB images also indicate this unit is more conductive compared to the units above and below. Such log response could indicate a clay-rich unit, possibly similar to the brown clay unit recovered from Leg 56 Site 436 (Shipboard Scientific Party, 1980b). Log Unit IV (835.9-850 mbsf) is characterized overall by low gamma ray and high resistivity values. RAB images primarily show regions of very high resistivity in layers and patches throughout this log unit. The resistivity and gamma response is consistent with lithologies, such as chert, and $\mathrm{RAB}$ images may indicate some interbedding of chert and a more conductive material. Chert was also observed below the brown clay at Site 436 (Shipboard Scientific Party, 1980b).

Bedding and fracture occurrence and orientation were determined from borehole resistivity images (Fig. F6). Three structural domains may be defined on the basis of bedding dip distributions: (1) upper frontal prism (0-275 mbsf) with more gently inclined bedding, (2) lower frontal prism (276-820 mbsf) with variable and steeply dipping beds, and (3) base section ( 820 mbsf to the base of the hole) with shallow to horizontal bedding. The poles-tobedding in the lower frontal prism are consistent with cylindrical folding with a mean axial trend of $030^{\circ}$, which is $\sim 20^{\circ}$ northeast of a line parallel to the regional slope and nearly normal to the convergence direction of $292^{\circ}$ (DeMets et al., 2010; Argus et al., 2011). Structural Domain 1 shows sparse fractures, whereas fractures are more numerous in Domains 2 and 3. Similar to bedding, the strike of fractures displays a preferred northwest orientation. A zone of 
enhanced fracturing occurs around a significant conductive feature at 720 mbsf. The feature is shown as a large negative excursion in the standard logs and a dark band in the RAB images, which may reflect a zone of faulting (Fig. F5). This feature was regarded as a potential site of the Tohoku-oki earthquake rupture and was targeted for coring; the feature is hereafter referred to as the 720 fault.

Another probable fault was identified at $820 \mathrm{mbsf}$ between structural Domains 2 and 3 and between $\log$ Units II and III; the feature is hereafter referred to as the 820 fault. The structural transition resembles that of a classic décollement, with variably dipping beds above and shallow dipping beds below that are sitting above the basaltic crust (Fig. F6) and are interpreted as a brown clay layer and chert layers characteristic of the incoming oceanic plate of the north Pacific Ocean (Shipboard Scientific Party, 1980b).

Breakouts were identified in the image logs of Hole C0019B and are found to occur over a broad depth range in log Units I and II and structural Domains 1 and 2 (Fig. F7). Breakout distributions display preferred orientations that vary with depth. The mean azimuth of breakouts in the deeper portion of the hole (537-820 mbsf) is $049^{\circ}$ and the standard deviation is $23^{\circ}$. Thus, the maximum horizontal compressive stress orientation can be interpreted as $319^{\circ} \pm$ $23^{\circ}$ at the base of the prism. At immediate depths, the breakouts are less frequent, and orientations are highly variable. In the shallower portion of the borehole, the orientation of breakout azimuth progressively rotates clockwise downhole to $140 \mathrm{mbsf}$ and then rotates back counterclockwise, suggesting the presence of a discontinuity, perhaps a fault. This is supported by a conductive peak in the resistivity logs. Changes in bedding dips are also consistent with the presence of a discontinuity at this depth.

\section{Downhole measurements and observatory}

No observatory components were deployed during the main portion of Expedition 343; however, some downhole observations were made to measure temperature and pressure using 1-3 of the MTLs (TDR2050) placed in the inner core barrel of the RCB coring assembly. Deplugger operations typically use the inner core barrel with a special center adaptor to clear the RCB bit; we used the inner barrel to hold the MTL sensors for in situ pressure and temperature measurements. The inner core barrel containing the instruments was deployed by a free-fall release down the drill pipe in a procedure that was developed on board the ship during the expedition. Three different measurement runs were completed on 12 May, 16 May, and 22-24 May.
Temperature measurements made within the borehole were highly affected by drilling operations, particularly measurements recorded during pumping and circulation. Although pumping and circulation was stopped prior to making the third run, we did not expect the borehole temperature to have equilibrated by the time measurements were taken, and this was confirmed by observations that the temperature changed with time even though the pipe was fixed in position.

Pressure measurements showed significant fluctuations, reflecting changes in depth of the instrument with time. The dominant signal indicated cyclic changes in depth consistent with ship heave. However, additional pressure variations were recorded that implied depth variations of much greater magnitude than the heave. It was determined that these large variations in pressure (depth) reflected vertical oscillations that were triggered by rapid accelerations of the drill stem or core line at the ship, as occurs for example during addition or removal of pipe stands and retrieval of the inner barrel holding the MTL sensors. This effect is magnified during free hanging of the extremely long drill stem and core line that were employed for the deepwater operations of this expedition.

During Expedition 343T in July, the temperature observatory consisting of MTLs was successfully deployed in Hole C0019D (Fig. F8). The instrument string of 55 MTLs was suspended in $4 \frac{1}{2} 2$ inch pipe from a hanger at the wellhead. Three types of MTLs from two different manufacturers were used, which differed in data storage volume. Also, some of the instruments included pressure sensors for accurate estimates of water depth. The sensors are designed to monitor the changing temperature at sample intervals of $10 \mathrm{~s}$ to 10 min over several months until their retrieval, which is scheduled for February 2013. Also, two of the instruments were programmed to turn on at high sample rates during the times of the anticipated retrieval in order to obtain a temperature profile during pullout. The MTLs are distributed over $\sim 550 \mathrm{~m}$, with dense spacing of $1.5 \mathrm{~m}$ near the 820 fault (Fig. F8). Because of the possibility of postseismic slip on the fault that may deform the borehole and cut the instrument string, weak links that can break at designated positions were interspersed along the instrument string to help minimize loss of MTLs.

\section{Lithology}

As a result of time constraints, only 21 coring runs at 4 depths were completed. Lithologic Unit 1 was sampled by a single spot core taken from the 176.5186.0 mbsf interval (Figs. F9, F10). The core consists of medium olive-gray siliceous mudstone with sec- 
ondary lithologies including isolated, few millimeter to $2 \mathrm{~cm}$ thick layers of yellowish gray ash and dark gray to black, millimeter-scale laminations with gradational contacts. The siliceous mudstone is dominated by abundant clay- to silt-sized siliciclastic material and includes abundant siliceous microfossils (diatoms, sponge spicules, and radiolarians) and common ash shards.

Lithologic Unit 2 was sampled by two coring runs taken from the interval 648.0-660.5 mbsf. Recovered sediment comprises bluish gray ashy mudstone and grayish brown ashy mudstone, both of which are heavily brecciated and thoroughly mixed throughout by drilling and recovery processes. Both mudstones contain dominant siliciclastic grains, common volcaniclastic grains, and biogenic fragments that are present and occasionally common.

The sediment of lithologic Unit 3 was relatively well sampled from 13 coring runs covering intervals 688.5-729.0 and 770-821.5 mbsf (Fig. F9). Unit 3 comprises four dominant lithologies: olive-browngray ashy mudstone, dark gray mudstone with black interlayers, clay-rich mudstone, and dark gray mudstone with abundant pyrite. These units are interbedded on a meter scale with occasional centimeterscale interlayers and intermittent centimeter-scale clay and silt beds. All lithologies are dominated by siliciclastic material and contain trace or present siliceous microfossils and fossil fragments, with rare horizons containing up to $15 \%$ siliceous fragments. Ash is abundant in the ashy mudstone, but otherwise ash layers are rare and ash content decreases significantly downsection below the ashy mudstone. X-ray diffraction data show the overall quartz, feldspar, and clay content of Unit 3 is generally consistent throughout the section except for discrete clay and silt beds. Unit 3 has a much higher component of siliciclastic material and a lesser component of volcanic and siliceous grains than Unit 1 . Unit 3 contains none of the grayish brown or bluish gray ashy mudstones of Unit 2. Unit 3 reflects a more terrigenous environment of accumulation than Units 1 and 2 and a time of lesser accumulation of siliceous microfossils and increased distance from, or lesser activity of, volcanic sources.

Unit 4 occurs in only one core taken from the interval 821.5-824.0 mbsf (Fig. F10). Unit 4 consists of strongly deformed clays that are pervasively sheared, forming sharp, strongly aligned lenses with polished, striated surfaces defining a scaly fabric. Two main components can be recognized from visual inspection and smear slide analysis: red-brown clay and dark brown to black clay. The reddish brown clay is composed predominantly of clay minerals with rare coarser grains and vitric grains, whereas the dark clay is composed mainly of dark red-brown clay minerals probably mixed with Fe or Mn oxides/hydroxides. Sections $0.5-4 \mathrm{~cm}$ thick of reddish to dark brown and black clay alternate at the top of the core. A 13 $\mathrm{cm}$ section of gray mudstone is enclosed inside the clay. Downsection from the mudstone interval, dark brown to black clay is dominant. The foliation defined by the scaly fabric varies from horizontal to $\sim 35^{\circ}$ inclination. The upper and lower contacts of Unit 4 with Unit 3 above and Unit 5 below were not captured in the recovered core section.

Unit 5 is yellowish to grayish brown mudstone composed of dominant siliciclastic grains, minor volcaniclastic grains, and trace siliceous microfossils (radiolarians). The siliciclastic component of the rock is predominantly clayey in the upper part of the unit ( $>60 \%$ clay and $<40 \%$ silt) and becomes more silty in the lower part $(<60 \%$ clay and $>40 \%$ silt) with trace sand. Bedding is often indistinct but is loosely defined by alignment of the long axes of the elliptical lenses of all colors. The contact between Units 5 and 6 is contained in Core 343-C0019E-20R, and it appears conformable and is likely stratigraphic. The overall nature of the unit, particularly the dominance of silt in the lower portion, indicates a significant influx of siliciclastic and terrigenous material relative to the biogenic and pelagic clay deposits in Unit 6 below.

Unit 6 comprises laminar yellow-brown and dark brown clay with occasional pink, red-brown, and white laminae. It is $0.65 \mathrm{~m}$ thick, occurs within the lower portion of Core 343-C0019E-20R, and is in contact with Unit 5 above and Unit 7 below. The unit consists of $>80 \%$ siliclastic grains with $<10 \%$ volcanic grains and trace to $10 \%$ siliceous microfossils. Diatoms are not observed in this interval, but radiolarians are present. More than $75 \%$ of the material falls in the clay grain size fraction. The bottom section consists of green to light green clays and gradationally transforms into chert (Unit 7). Radiolarian molds are present in the basal section of Unit 6 . Unit 6 is interpreted as pelagic clay deposited on the incoming Pacific plate.

Unit 7 consists of yellow-brown and chocolatebrown laminar chert that occurs as fragments at the base of Core 343-C0019E-20R and in Core 21R, taken from the interval $831-844.5 \mathrm{mbsf}$ (TD). Similarity in color and lamination of the chert to that observed in the overlying clay and the intermixing of clay and chert observed in Cores 20R and 21R suggest that the underlying chert is formed by chertification of the clay. The transition from the pelagic clays in Unit 6 to the chert in Unit 7 was not sampled directly, but the presence of chert nodules and intercalated chert layers within Unit 6 suggests the transition is a dia- 
genetic front. Unit 7 is correlated to the chert recovered in the incoming Pacific plate during Leg 56 at Site 436 (Shipboard Scientific Party, 1980b). Similar to Leg 56, the fine-scale laminations within the chert represent the only primary sedimentary structures, implying minimal transport and reworking of the clays prior to chertification.

Site 436 is located off northern Honshu and represents the most proximal drilling site that can be used as a reference for the incoming section cored at Site C0019. Site 436 consists of three lithologic units: the upper unit is vitric diatomaceous silty clay and claystone, the middle unit is radiolarian diatomaceous claystone, and the basal unit is pelagic clay with chert and porcellanite. The upper and middle units at Site 436 are lithologically similar to lithologic Units 1-3 at Site C0019, which are composed of mudstone, siliceous mudstone, and locally ashy mudstone. This lithologic description is very general and does not necessarily imply a direct correlation between the units in Hole C0019E and the incoming plate strata. Site C0019 Units 4-7 correlate to the basal unit at Site 436 . There are direct matches between the brown clay, the multicolored clays, and the chert between these unit correlations. For example, chert in Units 6 and 7 closely resembles descriptions of chert at Site 436 interval 378.5-397.5 mbsf, in which scarce Albian-Cenomanian radiolarians indicate a Cretaceous depositional age (Shipboard Scientific Party, 1980b). However, a direct equivalent of Site C0019 Unit 5 (brown mudstone) was not identified in the basal unit of Site 436. The lithology of Site C0019 Unit 5 could represent a stratigraphic variation between the two holes or could be structurally emplaced from the upper plate at Site C0019. The former interpretation is favored because of the absence of a sheared basal contact of Unit 5 at Site C0019. Better correlation between Site 436 and Site C0019 may be possible after the completion of the biostratigraphic analyses.

\section{Structural geology}

Investigation of structures in core samples through combined X-ray computed tomography (CT) imaging and visual observation provided a wealth of data that both verify and extend the structural data derived from the LWD/MWD borehole logs. Within the intervals sampled by coring, numerous orientation measurements of bedding and fractures and orientation and kinematics of faults were obtained. Determination of paleomagnetic poles to correct bedding strike to true azimuths have not yet been completed, so here we concentrate on dip magnitudes and shear sense indicators.
In core samples from lithologic Unit 1 in structural Domain 1, direct measurement of bedding indicates a dip magnitude of $30^{\circ}$. Faults are diffuse, narrow (few millimeters thick) zones of deformed sediment with similar composition to the adjacent sediment. In the X-ray CT images, faults are tabular zones of material with high CT number (which appear as bight features), several millimeters thick, that truncate and offset worm burrows and bedding they intersect. Fault surfaces in the core are polished and display slickenlines defined by aligned clay particles, which are correlated to bright planes. Of 10 mapped faults, all are dip-slip. Three are normal faults, and the shear sense of the others was not determined. Fault dip averages $66^{\circ} \pm 9^{\circ}$, ranging from $55^{\circ}$ to $81^{\circ}$. Measured offsets are of the order of $1 \mathrm{~cm}$, but several faults had offsets greater than the diameter of the core. Both bedding and fault dip determined from the core are consistent with bedding and fracture orientations determined from image logs.

Because of the extreme brecciation of core containing lithologic Unit 2, few structural measurements were possible. A single probable bedding surface that dips $\sim 3^{\circ}$ is marked by a dark band that grades gradually darker toward the top of the core. Additionally, five dip-slip faults were identified. Some were recognized in CT images as bright surfaces cutting burrows and were then located in core. Of the faults, one was inferred as a normal shear sense. Fault dip is variable, ranging from $\sim 10^{\circ}$ to steeper than $70^{\circ}$.

Coring from 688.5 to 729.0 and 770 to 821.5 mbsf sampled lithologic Unit 3 and structural Domain 2 across the 720 fault to the 820 fault (Fig. F10). Core observations confirm the variation in bedding dip magnitude determined from the image logs and define patterns in dip magnitude in particular intervals. Between 660 and $680 \mathrm{mbsf}$, bedding dips average $37^{\circ} \pm 20^{\circ}$ and are variable through the entire interval. From $\sim 770$ to 790 mbsf, steeper dips dominate, including some potentially overturned intervals with very steep dips (average $64^{\circ} \pm 15^{\circ}$ ). From $\sim 800$ mbsf to the base of the unit at $\sim 820 \mathrm{mbsf}$, moderate dips dominate (average $38^{\circ} \pm 11^{\circ}$ ).

The most common structures observed in Unit 3 over the depth intervals 688.5-729.0 and 770-821.5 mbsf are dark seams and dark bands. Dark seams are planar to curviplanar and are $<1 \mathrm{~mm}$ in thickness (usually hairline $\sim 100 \mu \mathrm{m}$ width), whereas dark bands are tabular or curviplanar to irregular with thickness ranging from $<1$ to $2-3 \mathrm{~mm}$ along their length. On the CT images, most dark seams and some dark bands are marked by bright seams and bright bands, respectively, with higher CT numbers than those of the surrounding material. The different characteristics of these features were investigated 
both visually and in X-ray CT imaging. The truncation and offset relationships and X-ray CT brightness properties suggest dark seams are likely solution surfaces or very thin shear surfaces, whereas dark bands are usually shear bands but may also rarely be bedding or bedding-parallel shear bands. The dip angles of these features are highly variable throughout and occur over a range of dips at each depth interval. However, overall low-angle faults are more prevalent deep in the section between 800 and 820 mbsf.

A noteworthy zone of fractured and brecciated sediment occurs between 719 and 725 mbsf (Fig. F10). Over a $0.27 \mathrm{~m}$ interval centered around $719.85 \mathrm{mbsf}$, beds are crosscut and offset by a $15 \mathrm{~mm}$ thick, anastomosing, $60^{\circ}$ dipping fault zone. This feature correlates quite closely with an interval of low resistivity identified in resistivity image logs from the neighboring Hole C0019B (i.e., the 720 fault). From 719 to 725 mbsf (below the fault), the mudstone is broken into angular fragments ranging from 1 to $10 \mathrm{~cm}$ in diameter along sets of inclined fractures that may be parallel to, or exploit, dark seams. The fractures are commonly polished and slickenlined and sharply cut burrows and the mottled texture and compositional layering in the mudstone. Stepped slickensides and drag of bedding along the fault indicates reverse shear sense.

Another notable fault (at 697.2 mbsf) was identified in CT images as a $\sim 2-7 \mathrm{~mm}$ thick bright band that dips $10^{\circ}$ with respect to a horizontal plane. The section above the bright band shows inclined fissility in homogeneous sediment, whereas fissility is absent in the section below, which is distinctively mottled, suggesting a slip magnitude sufficient to juxtapose different sedimentary layers. The interval including the bright band was taken as a structural wholeround sample because this interval is close to the location of an $\mathrm{H}_{2}$ anomaly at 697.9 mbsf; the sample was not further described during the shipboard operations but will be the focus of some shore-based studies.

Unit 4 is only observed within, and makes up all of, Core 343-C0019E-17R. Structures in Unit 4 were identified from observation of the whole round and $\mathrm{X}$-ray CT images. Most of the core is composed of clay with a variably intense scaly fabric. There is also an interval (0.22-0.34 $\mathrm{m}$ from the top of the section) of relatively intact and only slightly sheared mudstone with upper and lower boundaries in contact with the sheared clay. The intense scaly fabric within the clay is characterized by polished, lustrous surfaces, commonly striated, enclosing narrow, variably shaped and sized lenses of less fissile material, termed phacoids. The major and intermediate axes of the phacoids define the dominant, pervasive folia- tion. In any observation section, the phacoids appear bounded by surfaces with two predominant orientations, but locally one surface orientation predominates. In the uppermost $22 \mathrm{~cm}$ of the core, phacoids are sometimes asymmetric when viewed in a section perpendicular to the foliation and parallel to the dip direction of the foliation; the observed asymmetry indicates reverse shear sense.

In general, phacoid size increases with depth in Unit 4; however, there are several abrupt, discontinuous changes in color and phacoid size implying compositional and structural layering parallel to the foliation. The most finely foliated scaly fabric is observed between 0 and $0.20 \mathrm{~m}$, where the red-brown clay forms platy phacoids with minor axes $<1 \mathrm{~mm}$ in length. Within this interval, a visibly obvious curviplanar contact juxtaposes the predominantly redbrown clay and predominantly dark brown to black clay. The contact surface is slightly wavy at the centimeter scale with amplitudes $<1 \mathrm{~mm}$; the foliation on either side is truncated without deflection at the contact. These features are consistent with a meters thick shear zone hosting mesoscopic-scale surfaces of localized slip.

The interval of intact mudstone bounded by the sheared clay layers above and below displays three major sets of intersecting dark seams, some of which offset each other by a few millimeters. The major dark seams are shallow dipping subparallel to the bounding surfaces. The deformation features on the mudstone interval are similar to those observed within lithologic Unit 3 in Core 343-C0019E-15R, as well as to the fracture sets that were opened during drilling in the top of Unit 5 (Cores 18R and 19R). Deformation of the mudstone may have occurred during shearing of the entire unit. Alternatively, because similar structures are observed in Units 3 and 5, the observed deformation could predate the incorporation of the mudstone as a tectonic lens within the sheared clay.

Overall, the sheared zone of clay displaying scaly fabrics in Core 343-C0019E-17R markedly contrasts with relatively coherent and much less deformed sediments recovered from above and below Core $17 \mathrm{R}$. The fact that the primary bedding has been completely destroyed by shear deformation and a penetrative scaly fabric containing localized slip surfaces developed in the layer indicates it has accommodated significant shear displacement and constitutes the core of a major fault. The total thickness of the sheared clay layer is unknown because the upper and lower contacts were not recovered and recovery of Core $17 \mathrm{R}$ was $38.8 \%$. If unrecovered intervals in Cores 16R-18R are also composed of sheared clay, the maximum thickness of the sheared zone is 
$4.86 \mathrm{~m}$. Regardless of true thickness, the structure of the layer is compatible with displacement on the order of thousands of meters of slip. Also compatible with significant displacement is the abrupt change in lithology and bedding dip across the interval of scaly clay; the sediments in the hanging wall show moderate dip magnitudes and those in the footwall are subhorizontal. Moreover, the footwall strata are consistent with a pelagic sediment sequence deposited on the oceanic crust of the Pacific plate and thrust under the prism sediments in the hanging wall. Thus, the sheared clay interval at 821.5-822.5 mbsf is interpreted as the plate boundary décollement between the subducting Pacific plate and the overlying prism of accreted sediment (Fig. F10). It is noteworthy that the scaly clay zone is more similar to the décollement zones in Costa Rica (e.g., Kimura, Silver, Blum, et al., 1997; Vannucchi and Tobin, 2000) and considerably thinner than the few tens of meters thick décollement zones in Nankai and Barbados (Maltman et al., 1997; Wallace et al., 2003; Kinoshita et al., 2008).

The brown silty clayey mudstone of lithologic Unit 5 displays progressively less deformation downward and a relatively undisturbed state at the basal contact with Unit 6 . The unit is relatively homogeneous and bedding orientation is not clear on the core surface, possibly due to extensive bioturbation indicated in X-ray CT images. However, the sedimentary contact at the base of this unit dips $7^{\circ}$, similar to the few observed stratigraphic contacts within the unit. The unit is traversed by shear fractures and locally dark bands. These brittle deformation features are observed in the cut surface as well as in CT images. Located near the top of the unit are discrete zones of particularly high fracture density, and incipient scaly fabrics may be indicated by intersecting fracture networks in zones $<0.10 \mathrm{~m}$ thick. Shear surfaces within this unit, particularly near the base, dip between $31^{\circ}$ and $62^{\circ}$, averaging $\sim 45^{\circ}$.

The primary structural features in Units 6 and 7 are bedding surfaces in the clays that on average dip $6^{\circ} \pm$ $2^{\circ}$ and three natural faults dipping $14^{\circ}, 55^{\circ}$, and $78^{\circ}$. Other apparent faults probably result from drillinginduced damage, as they are bounded by significant amounts of soft, structureless, intruded clay. Overall, intact lamination in Unit 6 indicates that very little structural deformation or bioturbation affected these bedded units of the underthrust section.

\section{Biostratigraphy}

Although samples were collected during the expedition, the actual analysis will be performed by a shore-based specialist (I. Motoyama et al., unpubl. data).

\section{Geochemistry}

Interstitial water samples were taken from 12 cores collected during this expedition. Interstitial water geochemistry and headspace samples were processed aboard the $\mathrm{D} / \mathrm{V}$ Chikyu. Interstitial water samples showed evidence of a sulfate-bearing fluid reservoir at depth, which on the basis of the condition of the intact whole-round sections sampled is unlikely to be from drilling-induced contamination. Chlorinity and bromide also decreased with depth, consistent with the presence of a reservoir of deeper, fresher fluids.

Gas chemistry, particularly the presence of varying $\mathrm{H}_{2}$ concentrations, may reflect mechanochemical production of $\mathrm{H}_{2}$ during high-velocity frictional sliding and sediment disruption, as would be expected for the Tohoku-oki earthquake. Although the sampled interval is not complete and is therefore missing some key zones, the presence of an isolated spike increase in $\mathrm{H}_{2}$ concentration in Section 343-C0019E5R-1 suggests the presence of a recently activated fault. Below this location, methane concentrations gradually decrease with depth and reach a minimum in Section 20R-2 that is 2-3 orders of magnitude less than the core above it; this also suggests that methane concentrations have been dissipated through subseafloor fluid flow and supports the presence of a deeper reservoir of fluids.

\section{Microbiology}

Twelve whole-round core samples were taken from various depths in Hole C0019E, and sampling procedures were completed within $60 \mathrm{~min}$ of the core arriving on deck. Fixed samples were stored at $-80^{\circ} \mathrm{C}$ for later DNA/RNA analyses. Results of the contamination tests using perfluorocarbon (PFC) tracer, which was added to the drilling mud, show PFC was present in the exterior portions of the whole-round samples. Also, some PFC contamination was present in the interior portions of Cores 343-C0019E-5R, 7R, $8 \mathrm{R}, 15 \mathrm{R}$, and $20 \mathrm{R}$ but not inside of Cores $4 \mathrm{R}, 12 \mathrm{R}$, and 19R. Microbiological and interstitial water data will be carefully evaluated to assess the degree of possible contamination from drilling mud and seawater.

\section{Physical properties}

Bulk density of core samples determined from moisture and density (MAD) measurements and from gamma ray attenuation measured by the wholeround multisensor core logger (MSCL-W) compare favorably. The density values generally increase with 
depth as expected for mechanical consolidation. Discrete samples taken from the 820 fault (Unit 4) have a bulk density of $1.98 \mathrm{~g} / \mathrm{cm}^{3}$, whereas in the clay-rich zone just below the fault, bulk density values range from 1.76 to $2.03 \mathrm{~g} / \mathrm{cm}^{3}$. Porosity determined from MAD measurements decreases with depth from $55.3 \%-68.7 \%$ at shallow levels to $~ 45 \%-50 \%$ in the vicinity of the 720 and 820 faults. The lowest values are found in the immediate vicinity of the 720 fault zone, compatible with shear-enhanced compaction.

Overall, resistivity of discrete samples from lithologic Unit 1 and into Unit 3 increases with depth but is lowered locally, possibly from the presence of ash layers. Resistivity markedly increases from the lower part of Unit 3 into Unit 4. In Units 5 and 7 from 826 to 836 mbsf, below Unit 4, resistivity is again significantly lower. Resistivity is high within the chert of Unit 7.

Qualitatively consistent with logging data, natural gamma radiation (NGR) data from the MSCL-W measured on whole rounds indicate the NGR magnitude in Unit 4 is about twice that in units above, consistent with a significant increase in the clay fraction from Unit 3 to Unit 4. NGR decreases progressively from Unit 4 downhole, indicating a gradual decrease in clay content in Units 5 and 6.

$P$-wave velocity measured on unconfined discrete samples ranges from 1400 to $3300 \mathrm{~m} / \mathrm{s}$, but there is a clear trend of increasing velocity with depth. There is a decrease in the velocity measured on samples from lithologic Unit 5, below the 820 fault zone. A maximum velocity of $\sim 3272 \mathrm{~m} / \mathrm{s}$ occurs in the cherts of Unit 7. $P$-wave velocity has an inverse relationship with porosity, with the majority of samples following an approximately linear trend except for the chert, which has a much higher velocity. On five select cubic samples, both $P$ - and $S$-wave velocities were measured in multiple directions under stepwise increasing and decreasing confining pressure to determine pressure dependence and anisotropy. These measurements are useful for determining seismic properties at in situ pressures, as well as for inferring properties of similar sediments at greater depths in the wedge.

Thermal conductivity was measured on the working half of core sections at 45 discrete locations; the mean of all measurements is $1.139 \mathrm{~W} /(\mathrm{m} \cdot \mathrm{K})$ (standard deviation $=0.118 \mathrm{~W} /[\mathrm{m} \cdot \mathrm{K}]$ ). Significant deviation from the mean occurs in Unit 1 with a mean of $0.874 \mathrm{~W} /(\mathrm{m} \cdot \mathrm{K})$ (standard deviation = $0.0141 \mathrm{~W} /[\mathrm{m} \cdot \mathrm{K}], n=2)$, in Unit 6 with a mean value of $1.086 \mathrm{~W} /(\mathrm{m} \cdot \mathrm{K})$ (standard deviation = $0.0870 \mathrm{~W} /[\mathrm{m} \cdot \mathrm{K}], n=3)$, and in the chert of Unit 7 with a very high value of $1.622 \mathrm{~W} /(\mathrm{m} \cdot \mathrm{K})$ because of its high density and silica content.
Unconfined compressive strength (UCS) was determined for nine minicores from various depths. In general, UCS increases downhole, with locally low strength values exhibited by samples that may represent major faults or shear zones. In the lower portion of Unit 3 (below $800 \mathrm{mbsf}$ ), UCS is $6.4-7.6 \mathrm{MPa}$, but Unit 4 from the 820 fault zone immediately below shows lower strengths of 3.4 and $4.7 \mathrm{MPa}$. A chert sample from Unit 7 was the strongest tested, with a minimum UCS of $65.3 \mathrm{MPa}$.

\section{Core-Log-Seismic integration}

Core, log, and seismic data are integrated, and the identified log units and structural domains, seismic units, lithologic units, and major structural features are compared in order to develop a unified interpretation of the geology and geophysics of the drill site. Unfortunately, core was acquired from only a portion of the entire drilled section, albeit from critically important sections, so, where possible, core samples were used to ground truth lithologic interpretations of the logging data. Similarly, the limited suite of logging tools did not provide multiple independent measures of rock properties such as velocity, density, and porosity. Accordingly, to quantify density and seismic velocity, we determined formation factor from the resistivity logs, calculated porosity using Archie's law, and used direct measurement of discrete samples from core to constrain Archie's law. In addition, MSCL-W data were used as an intermediate step for correlation of discrete measurements from core and log data. Finally, to integrate core and log data with seismic data, a synthetic seismic trace was created for Hole C0019B. A wavelet was extracted from seismic Line HD33B, and the reflectivity series were calculated using density and velocity logs determined from resistivity-based porosity with some adjustment of the velocity model based on cross-correlation of seismic data and the synthetic seismic trace.

The log units, based on LWD gamma ray and resistivity responses, compare favorably with lithologic units identified through core analysis, particularly at the base of the borehole where contrasts in lithology and geophysical response are most dramatic (Fig. F10). The log Unit II/III, structural Domain 2/3, and lithologic Unit $3 / 4$ boundaries correlate exactly. The changes observed across this boundary, specifically the abrupt change in bedding dip seen in RAB image logs and core, the increase in clay content of core samples as reflected by the concomitant increase in gamma ray, $\mathrm{K}_{2} \mathrm{O}, \mathrm{Al}_{2} \mathrm{O}$, and $\mathrm{MnO}$, and the presence of the scaly clay fault-rock that make up lithologic Unit 4, point to this boundary as a significant fault contact. The similarity of the lithologic units seen in 
core below the boundary with strata deposited on the Pacific plate at Site 436 (Shipboard Scientific Party, 1980b) suggests this boundary is the plate interface (i.e., the décollement) (Fig. F10). Furthermore, the fact that observations of both the core samples and RAB image logs indicate that the entire sediment section above the boundary (structural Domains 1 and 2 and lithologic Units $1-3$ ) is variable, often steeply dipping and fractured, means it is consistent with a section comprising a shortened and accreted sequence of strata making up the frontal prism.

Above the plate boundary décollement and within the frontal prism, the log unit boundaries, structural domain boundaries, and lithologic boundaries do not correlate well (Fig. F10). Boundaries demarcated on the basis of changes in stress indicated by borehole breakout patterns also do not correlate. Moreover, the entire prism (seismic Unit A) at Site C0019 lacks coherent or continuous reflectors and appears relatively transparent in seismic profiles. This likely reflects both the presence of inclined and faulted bedding and the relatively uniform properties of the sediment. Although the spot cores taken at 176.5186.0 and 648.0-660.5 mbsf are considered to represent different lithologic units, both of these sections, as well as core from deeper intervals in the prism (688.5-729.0 and 770-821.5 mbsf), are mudstones composed predominantly of terrigenous silt and clay with varying amounts of vitric ash and biogenic silica. The subtle cyclicity in gamma ray and resistivity log response with depth in the prism may result from stacking folded packages of sediment by thrust and reverse faulting. The apparent gradual decrease in porosity with depth from progressive consolidation interrupted by stepwise increases in porosity from faulting is consistent with such a structural interpretation. Given the variable but dominantly steep eastward dip of the sediment throughout most of the prism (Fig. F6), even relatively small displacement on contractional faults would lead to significant repetition of strata as seen in a vertical borehole.

Although log, structural, and lithologic boundaries do not correlate well in the prism, correlations are noted between abrupt changes or discontinuities in different signals at a couple of different locations in the prism. For example, at $~ 140$ mbsf, an abrupt reversal in the progressive change in borehole breakout orientation correlates with a sharp change in bedding from moderate dips to very shallow dips, which likely reflects a fault contact. Another marked change in borehole breakout distribution occurs at $\sim 550$ mbsf and appears to correlate with a local low gamma ray response. The 720 fault and bounding fractured zone identified on the basis of RAB image logs and resistivity curves correlates with the fault zone at 719-725 mbsf and the geochemical anomaly at 700 mbsf identified in core samples (Fig. F10). In addition, the 720 fault coincides with an abrupt change in bedding dip documented in both logs and core.

Regional seismic images display three prominent seismic units below the lower slope of the Japan Trench where Site C0019 boreholes were drilled (Fig. F9). Uppermost seismic Unit A is wedge-shaped with an acoustically chaotic character and without continuous reflectors and corresponds to the frontal prism. Seismic Unit B consists of a relatively thin section of fairly continuous subhorizontal reflectors located below Unit A and above Unit C. Lowermost seismic Unit $\mathrm{C}$ is the acoustic basement likely corresponding to oceanic igneous crust. Generation of the synthetic seismic trace based on resistivity logs, discrete core sample measurements of density and seismic velocity, and correlation with the seismic profile through the drill site allows location of the plate boundary fault in the seismic profile.

The synthetic seismic trace shows five possibly significant reflectors at the seafloor and at 70, 269, 368, and 839 mbsf. The middle three reflectors on the synthetic trace, at 70, 269, and $358 \mathrm{mbsf}$, fall within chaotic seismic Unit A. Coherent reflectors within this unit are rare and, where present, are often masked by steeply dipping noise, making confident correlation within the unit difficult. Moreover, bedding at these depths in the borehole dip moderately to steeply and are thus unlikely to be apparent in seismic sections. The lowermost strong reflector on the synthetic trace falls within bedded seismic Unit B. After cross-correlation-based alignment with the strong reflectors at the base of the borehole, the synthetic reflector at 839 mbsf correlates best with the first strong reflector of the bedded unit at $9994 \mathrm{~ms}$ two-way traveltime. In the borehole, the plate boundary décollement occurs at $\sim 820$ mbsf, $\sim 20 \mathrm{~m}$ shallower than the prominent reflector (Fig. F9).

\section{Preliminary scientific assessment \\ Objective 1: identify and sample the fault that ruptured during the Tohoku-oki earthquake}

The primary scientific motivation for this expedition was to gather time-sensitive information on the stress state, chemical processes, and energetics of the Tohoku-oki earthquake rupture at the toe of the prism. A prerequisite to achieving these goals was to locate, sample, and instrument the fault that slipped 
during the Tohoku-oki earthquake. To this end, a major accomplishment of the expedition was the successful completion of three holes at Site C0019 that reached the depth of the regionally distinct seismic reflectors generally interpreted as the top of the igneous basement of the subducting Pacific plate (e.g., Tsuru et al., 2002; Kodaira et al., 2012). After the completion of the LWD/MWD hole to the target depth, we confidently assumed we had drilled across the zone of the Tohoku-oki earthquake rupture as well as across the plate boundary interface. Moreover, contrary to expectations prior to drilling, borehole stability was not a significant issue at any depth in the hole. Thus, we concluded that hole conditions would not prevent installation of a temperature measurement observatory and that from temperature measurements we could verify the location of the earthquake rupture, provided we could identify, locate, and instrument the fault(s).

The original operations plan to use LWD/MWD data to locate the fault zone that ruptured during the Tohoku-oki earthquake required an extremely quick analysis that, in hindsight, was overly optimistic. As a result of operational delays, however, we had additional time to process and analyze the logging data more completely. Thus, we were able to confidently identify two significant fault targets for instrumentation and coring. The shallower fault target, the 720 fault, appeared as a meter thick, highly conductive layer within a zone possibly tens of meters thick containing variably dipping sediment cut by conductive and resistive fractures. This feature seemed to match expectations for an earthquake rupture zone (i.e., a localized shear zone), possibly composed of gouge, within a broader zone of fractured and brecciated sediment (e.g., Sibson, 2003; Vannucchi and Tobin, 2000). However, the lack of apparent change in lithology or borehole breakout patterns across the zone does not support the interpretation of a large displacement fault. The deeper fault target at 820 mbsf was identified on the basis of an apparent marked change in structure and lithology. Specifically, image log data showed the prism comprises a northeastward striking but variably dipping stack of sediments, as would be produced by folding and faulting during northwestward convergence and accretion. Steeply dipping beds near the base of the prism are truncated and in sharp contact with a very shallow dipping, concordant sequence of interbedded sediments that appeared to coincide with the regional seismic reflector associated with the top of the oceanic crust of the Pacific plate. The gamma ray and resistivity log responses of the sediment below the contact indicate distinct lithostratigraphic units, unlike the $\log$ responses of the sediment in the prism above. Overall, the abrupt structural and lithologic change across the contact is strongly suggestive of a plate boundary décollement between a deformed prism above and subducting oceanic crust below. However, the contact itself is unremarkable in image logs and displays little evidence of an associated fractured or brecciated zone with lowered resistivity as might be expected for a plate boundary fault zone recently ruptured by a great earthquake.

The two faults identified on the basis of LWD/MWD data were treated as equally important targets in planning the temperature measurement observatory and the coring hole. Accordingly, the location and spacing of the MTLs in the observatory was modified to acquire adequate measurement of temperature transients near either of the targets. The installation of the temperature measurement observatory remained the highest priority throughout the expedition, at least until the underwater television (UWTV) cable failed and could not be repaired. Without the UWTV it was not possible to install the observatory. At this point, coring operations commenced, but the remaining time was very limited. Accordingly, we devised a plan to core only across each of the primary targets, and that included taking very short coring runs over the several meters spanning the fault to maximize recovery.

Shipboard observations of the samples collected from the second coring hole confirmed the inferences drawn from the LWD/MWD data set and clarified the nature of the targeted fault features. All cores taken from the prism (i.e., from depths shallower than the 820 fault) consist of clayey to silty mudstones comprising terrigenous silt and clay, vitric ash, and biogenic silica. Measurements of bedding orientation in cores from the prism show locally variable dip, as well as the existence of discrete changes in dip as might occur across faults. The entire suite of core samples taken from the prism is variably dissected by dark shear bands and open fractures that are tectonic in origin, or other tectonic discontinuities that were opened by drilling. A prominent fractured and brecciated zone extends from 719 mbsf to deeper than 725 mbsf and bounds the prominent low-resistivity 720 fault. Several core samples from the fractured and brecciated zone contain minor faults, the largest and most prominent of which is a high-angle reverse fault that occurs at the same depth as the low-resistivity feature in the RAB image logs. Although no geochemical anomaly was identified in the fractured and brecciated zone near the 720 fault, a local $\mathrm{H}_{2}$ and chlorinity anomaly was documented near 700 mbsf. The increase in $\mathrm{H}_{2}$ may have been generated by recent faulting, and the local 
reduction in chlorinity could reflect focused flow of fluids from a deeper source.

Data from core samples support the overall interpretation made on the basis of logging data that the 820 fault is the plate boundary décollement between the deformed sediments of the prism above and the basal sedimentary strata and igneous oceanic crust of the incoming Pacific plate below. Core samples clearly document an abrupt and marked change in bedding dip at the 820 fault; although it is not at all apparent in the logging data, a zone of highly sheared clay is present below the contact and was sampled by the coring. The zone is between 1 and $5 \mathrm{~m}$ thick and is characterized by a scaly fabric that, locally, is penetrative to the millimeter scale. Immediately above and below the sheared layer, visual and X-ray CT observations document that the deformation intensity of the sediment and sediment density decreases rapidly with distance from the layer in a manner consistent with typical fault-related damage patterns. Lithologically, the multicolored clay layers and chert in the footwall of the 820 fault closely match the descriptions of the pelagic sediments recovered from the base of the drill hole on the Pacific plate east of the Japan Trench (Leg 56 Site 436; Shipboard Scientific Party, 1980b) and contrast markedly from the terrigenous sediments in the hanging wall of the décollement. The coincident lithologic and bedding discontinuity across the layer, the presence of deformed sediments bounding the layer, and the shear fabric of the clay in the layer are all compatible with the interpretation of a large displacement, plate boundary décollement.

The location of the décollement coincides with the uppermost reflector of the several distinct and parallel reflectors that demarcate the top of the subducting oceanic plate (Fig. F9). As shown by the in-line seismic profile that passes through the drill site, this reflector can be traced from the site $\sim 1.2 \mathrm{~km}$ to the east-southeast and several kilometers to the westnorthwest above the horst. The cross-line seismic profile that passes through the drill site indicates the reflectors are continuous several kilometers parallel to the trench as well. Approximately $1.2 \mathrm{~km}$ in-line to the east-southeast, the basement is down-dropped along a normal fault to form a prominent sedimentfilled graben that spans the axis of the trench. A distinct reflector continues from the top of the horst to the east and into the sediment fill of the graben (Fig. F2). The seismic character along this reflector is consistent with the general seismic structure of the décollement documented at the drill site (i.e., a hanging wall characterized as chaotic and seismically transparent [seismic Unit A] and a footwall consist- ing of subhorizontal seismic reflectors representing the bedded sediments [seismic Unit B] conformable with the underlying igneous basement of the subducting plate [seismic Unit C]). Thus, the reflector that continues from the horst into the graben and cuts some sediment layers in the footwall defines the décollement at the base of the displaced and thickened prism. The seismic data support the simple interpretation that the prism extends some $5 \mathrm{~km}$ east from the drill site to the axis of the trench (Fig. F2; also see Kodaira et al., 2012). A first-order palispastic reconstruction of the prism, assuming constant area balancing, implies the displacement on the décollement at the drill site is on the order of $3 \mathrm{~km}$. Although the deformation associated with the décollement is much more localized than that seen at other subduction décollements (e.g., Nankai, Barbados), the structure and fabric of the décollement at the drill site is compatible with displacements of this magnitude. Thus it is expected that the décollement at the drill site is likely continuous with the deeper portions of the plate boundary interface tens of kilometers downdip. A plate boundary décollement of this size and position is hypothesized as the locus of tectonic displacement of the subducting plate in the geologic past, as well as during the recent rupture that propagated to the trench during the Tohoku-oki event.

After analysis of core samples from both the 720 and 820 fault zones, the design of the MTL autonomous observatory was modified to primarily target the 820 fault using a dense array of sensors; however, sensor placement to allow characterization of a possible temperature anomaly at the 720 fault has been retained. In addition, some sensors are programmed to acquire data at higher frequencies at the time of scheduled retrieval in order to directly measure a temperature profile of the entire hole as the string is pulled out. Thus, the observatory is expected to provide valuable data when the sensor string is later retrieved, which is scheduled for February 2013. The observatory data will document the spatial and transient character of the temperature distribution in the lower reaches of the borehole (Fig. F8). These results will not only allow confirmation that the rupture occurred at the décollement but will also lead to a robust estimate of the frictional heat generated during the dynamic slip of the Tohoku-oki earthquake. The determination of total heat can constrain models used to estimate the dynamic shear strength of the fault and infer the magnitude of the coefficient of friction. 


\section{Objective 2: what was the stress state on the fault that controls rupture during the earthquake and was the stress completely released?}

The most significant goal of this rapid response drilling project is to determine the dynamic frictional stress. Data from the measurement of the time decaying temperature anomaly associated with the earthquake slip will be used to estimate the frictional heat produced at the time of the earthquake, which can be used to infer the level of dynamic friction (e.g., Brodsky et al., 2009; Fulton et al., 2010). Measurements of current stress (i.e., postearthquake slip) also can be used to explore different models to explain how dynamic slip occurred and the degree to which stress was released. The in situ stress is also determined through the use of LWD image logs to characterize borehole deformation (e.g., Zoback et al., 2003) and measurements of anelastic strain recovery (ASR) of core samples (e.g., Byrne et al., 2009). Several samples were collected for ASR, and these time-sensitive measurements were begun during this expedition. Measurements and analysis will be completed within several months after the end of the expedition and, if successful, could provide true 3-D determination of in situ stress in the prism.

The borehole breakouts evident in image logs from the LWD hole indicate several different in situ stress domains within the prism (Fig. F7). At depths less than 200 mbsf, the maximum horizontal compressive stress $\left(S_{\text {Hmax }}\right)$ systematically varies from approximately parallel to the convergence direction to perpendicular (at 140 mbsf) and back toward parallelism again with greater depth. At intermediate depths (200-537 mbsf), $S_{\text {Hmax }}$ orientation is variable and nonsystematic. At deeper levels in the prism (537-820 mbsf), $S_{\mathrm{H} \max }$ displays a single preferred orientation $\sim 20^{\circ}$ clockwise from the convergence direction. Faults and bedding are variable in dip magnitude, but faults and bedding at all depths in the prism show a preferred northeast strike direction reflecting horizontal contraction and local extension approximately parallel to the plate convergence direction. That $S_{\mathrm{H} \max }$ varies with depth in the prism likely indicates a postearthquake stress state in the prism in which $S_{\mathrm{H} \text { max }}$ is similar in magnitude to $S_{\mathrm{hmin}}$ except possibly in the very basal part of the prism. The variation at shallow depths can be understood as a result of reduction in the magnitude of the horizontal stress in the direction of slip during the earthquake. If the magnitude of maximum horizontal stress is reduced to values similar to the minimum horizontal stress, then borehole breakout directions will reflect local perturbations and appear highly variable or they may change systematically with depth because of variation in mechanical properties or the presence of other tectonic discontinuities.

Thus, these preliminary data on $S_{\mathrm{H} \max }$ directions are consistent with a large reduction of shear stress on the megathrust during the Tohoku-oki earthquake, but further analysis is necessary to infer the magnitude of stress changes.

\section{Objective 3: what are the characteristics of large earthquakes in the fault zone, and how can we distinguish present and past events in fault zone cores?}

Success in recovering $\sim 1 \mathrm{~m}$ of core from the highshear strain zone and neighboring sediments from the plate boundary décollement provides material for shore-based mechanical and physical properties testing, as well as for geochemical, mineralogical, and microstructural analyses. Physical properties testing, particularly for thermal and fluid-flow properties, are important for constraining models of thermal-mechanical-hydrological processes important to the seismic cycle, modeling thermal transients in order to infer the dynamic strength of the Tohoku-oki earthquake fault, and determining stress state of the prism over the seismic cycle. Several shore-based studies of frictional properties of intrafault materials as a function of slip rate, pressure, temperature, and fluids are planned; this information will feed into mechanical analyses of seismic faulting. In addition, four special interest structural whole-round samples taken from the sheared clay of the décollement, as well as three other structural whole rounds capturing secondary faults, will provide material for coordinated nondestructive and destructive investigations of structure, chemistry, and mineralogy of the faulted sediments. These studies and those of geochemistry and other physical properties will be used to search for signatures of seismic slip and investigate processes of dynamic slip during large earthquakes.

\section{References}

Ammon, C.J., Lay, T., Kanamori, H., and Cleveland, M., 2011. A rupture model of the 2011 off the Pacific coast of Tohoku earthquake. Earth, Planets Space, 63(7):693696. doi:10.5047/eps.2011.05.015

Apel, E.V., Bürgmann, R., Steblov, G., Vasilenko, N., King, R., and Prytkov, A., 2006. Independent active microplate tectonics of northeast Asia from GPS velocities and block modeling. Geophys. Res. Lett., 33(11):L11303. doi:10.1029/2006GL026077

Argus, D.F., Gordon, R.G., and DeMets, C., 2011. Geologically current motion of 56 plates relative to the no-net- 
rotation reference frame. Geochem., Geophys., Geosyst., 12(11):Q11001. doi:10.1029/2011GC003751

Arthur, M.A., and Adelseck, C.G., Jr., 1980. Acknowledgments, introduction, and explanatory notes: the Japan Trench transect, Legs 56 and 57, Deep Sea Drilling Project. In Scientific Party, Init. Repts. DSDP, 56, 57 (Pt. 1): Washington, DC (U.S. Govt. Printing Office), 3-21. doi:10.2973/dsdp.proc.5657.101.1980

Avouac, J.-P., 2011. Earthquakes: the lessons of TohokuOki. Nature (London, U. K.), 473(7356):300. doi:10.1038/nature 10265

Brodsky, E.E., Ma, K.-F., Mori, J., Saffer, D.M., and the participants of the ICDP/SCEC International Workshop, 2009. Rapid response fault drilling: past, present, and future. Sci. Drill., 8:66-74. doi:10.2204/ iodp.sd.8.11.2009

Byrne, T.B., Lin, W., Tsutsumi, A., Yamamoto, Y., Lewis, J.C., Kanagawa, K., Kitamura, Y., Yamaguchi, A., and Kimura, G., 2009. Anelastic strain recovery reveals extension across SW Japan subduction zone. Geophys. Res. Lett., 36(23):L23310. doi:10.1029/2009GL040749

Center for Deep Earth Exploration, 2012. IODP Expedition 343 drilling program. CDEX Tech. Rep., 16.

DeMets, C., Gordon, R.G., and Argus, D.F., 2010. Geologically current plate motions. Geophys. J. Int., 181(1):1-80. doi:10.1111/j.1365-246X.2009.04491.x

Fujii, Y., Satake, K., Sakai, S., Shinohara, M., and Kanazawa, T., 2011. Tsunami source of the 2011 off the Pacific coast of Tohoku earthquake. Earth, Planets Space, 63(7):815-820. doi:10.5047/eps.2011.06.010

Fujiwara, T., Kodaira, S., No, T., Kaiho, Y., Takahashi, N., and Kaneda, Y., 2011. The 2011 Tohoku-Oki earthquake: displacement reaching the trench axis. Science, 334(6060):1240. doi:10.1126/science.1211554

Fulton, P.M., Harris, R.N., Saffer, D.M., and Brodsky, E.E., 2010. Does hydrologic circulation mask frictional heat on faults after large earthquakes? J. Geophys. Res., [Solid Earth], 115(B9):B09402. doi:10.1029/2009JB007103

Hashimoto, C., Noda, A., Sagiya, T., and Matsu'ura, M., 2009. Interplate seismogenic zones along the KurilJapan Trench inferred from GPS data inversion. Nat. Geosci., 2(2):141-144. doi:10.1038/ngeo421

Ide, S., Baltay, A., and Beroza, G.C., 2011. Shallow dynamic overshoot and energetic deep rupture in the $2011 \mathrm{Mw}$ 9.0 Tohoku-oki earthquake. Science, 332(6036):14261429. doi:10.1126/science.1207020

Ito, Y., Tsuji, T., Osada, Y., Kido, M., Inazu, D., Hayashi, Y., Tsushima, H., Hino, R., and Fujimoto, H., 2011. Frontal wedge deformation near the source region of the 2011 Tohoku-oki earthquake. Geophys. Res. Lett., 38(15):L00G05. doi:10.1029/2011GL048355

Kanamori, H., Miyazawa, M., and Mori, J., 2006. Investigation of the earthquake sequence off Miyagi prefecture with historical seismograms. Earth, Planets Space, 58(12):1533-1541. http://www.terrapub.co.jp/journals/EPS/abstract/5812/58121533.html

Kimura, G., Silver, E.A., Blum, P., et al., 1997. Proc. ODP, Init. Repts., 170: College Station, TX (Ocean Drilling Program). doi:10.2973/odp.proc.ir.170.1997
Kinoshita, M., Tobin, H., Moe, K.T., and the Expedition 314 Scientists, 2008. NanTroSEIZE Stage 1A: NanTroSEIZE LWD transect. IODP Prel. Rept., 314. doi:10.2204/ iodp.pr.314.2008

Kita, I., Matsuo, S., and Wakita, H., 1982. $\mathrm{H}_{2}$ generation by reaction between $\mathrm{H}_{2} \mathrm{O}$ and crushed rock: an experimental study on $\mathrm{H}_{2}$ degassing from the active fault zone. $J$. Geophys. Res., [Solid Earth], 87(B13):10789-10795. doi:10.1029/JB087iB13p10789

Kodaira, S., No, T., Nakamura, Y., Fujiwara, T., Kaiho, Y., Miura, S., Takahashi, N., Kaneda, Y., and Taira, A., 2012. Coseismic fault rupture at the trench axis during the 2011 Tohoku-oki earthquake. Nat. Geosci., 5(9):646650. doi:10.1038/NGEO1547

Lin, W., Saito, S., Sanada, Y., Yamamoto, Y., Hashimoto, Y., and Kanamatsu, T., 2011. Principal horizontal stress orientations prior to the $2011 \mathrm{Mw} 9.0$ Tohoku-oki, Japan, earthquake in its source area. Geophys. Res. Lett., 38(17):L00G10. doi:10.1029/2011GL049097

Maltman, A., Labaume, P., and Housen, B., 1997. Structural geology of the décollement at the toe of the Barbados accretionary prism. In Shipley, T.H., Ogawa, Y., Blum, P., and Bahr, J.M. (Eds.), Proc. ODP, Sci. Results, 156: College Station, TX (Ocean Drilling Program), 279-292. doi:10.2973/odp.proc.sr.156.037.1997

Mori, J., Chester, F.M., Eguchi, N., and Toczko, S., 2012. Japan Trench Fast Earthquake Drilling Project (JFAST). IODP Sci. Prosp., 343. doi:10.2204/iodp.sp.343.2012

Ozawa, S., Nishimura, T., Suito, H., Kobayashi, T., Tobita, M., and Imakiire, T., 2011. Coseismic and postseismic slip of the 2011 magnitude-9 Tohoku-Oki earthquake. Nature (London, U. K.), 475(7356):373-376. doi:10.1038/nature10227

Sacks, I.S., Suyehiro, K., Acton, G.D., et al., 2000. Proc. ODP, Init. Repts., 186: College Station, TX (Ocean Drilling Program). doi:10.2973/odp.proc.ir.186.2000

Sato, M., Ishikawa, T., Ujihara, N., Yoshida, S., Fujita, M., Mochizuki, M., and Asada, A., 2011. Displacement above the hypocenter of the 2011 Tohoku-Oki earthquake. Science, 332(6036):1395. doi:10.1126/science. 1207401

Shipboard Scientific Party, 1980a. Site 434: the lower trench slope, Leg 56. In Scientific Party, Init. Repts. DSDP, 56, 57 (Pt. 1): Washington, DC (U.S. Govt. Printing Office), 355-398. doi:10.2973/ dsdp.proc.5657.106.1980

Shipboard Scientific Party, 1980b. Site 436: Japan Trench outer rise, Leg 56. In Scientific Party, Init. Repts. DSDP, 56, 57 (Pt. 1): Washington, DC (U.S. Govt. Printing Office), 399-446. doi:10.2973/ dsdp.proc.5657.107.1980

Sibson, R.H., 2003. Thickness of the seismic slip zone. Bull. Seismol. Soc. Am., 93(3):1169-1178. doi:10.1785/ 0120020061

Simons, M., Minson, S.E., Sladen, A., Ortega, F., Jiang, J., Owen, S.E., Meng, L., Ampuero, J.-P., Wei, S., Chu, R., Helmberger, D.V., Kanamori, H., Hetland, E., Moore, A.W., and Webb, F.H., 2011. The 2011 magnitude 9.0 Tohoku-Oki earthquake: mosaicking the megathrust 
from seconds to centuries. Science, 332(6036):14211425. doi:10.1126/science.1206731

Tsuru, T., Park, J.-O., Miura, S., Kodaira, S., Kido, Y., and Hayashi, T., 2002. Along-arc structural variation of the plate boundary at the Japan Trench margin: implication of interplate coupling. J. Geophys. Res., [Solid Earth], 107(B12):2357. doi:10.1029/2001JB001664

Tsuru, T., Park, J.-O., Takahashi, N., Kodaira, S., Kido, Y., Kaneda, Y., and Kono, Y., 2000. Tectonic features of the Japan Trench convergent margin off Sanriku, northeastern Japan, revealed by multichannel seismic reflection data. J. Geophys. Res., [Solid Earth], 105(B7):1640316413. doi:10.1029/2000JB900132

Vannucchi, P., and Tobin, H., 2000. Deformation structures and implications for fluid flow at the Costa Rica convergent margin, ODP Sites 1040 and 1043, Leg 170. J. Struct. Geol., 22(8):1087-1103. doi:10.1016/S01918141(00)00027-4

von Huene, R., Klaeschen, D., Cropp, B., and Miller, J., 1994. Tectonic structure across the accretionary and erosional parts of the Japan Trench margin. J. Geophys. Res., [Solid Earth], 99(B11):22349-22361. doi:10.1029/ 94JB01198

von Huene, R., Ranero, C.R., and Vannucchi, P., 2004. Generic model of subduction erosion. Geology, 32(10):913-916. doi:10.1130/G20563.1

Wallace, G., Moore, J.C., and DiLeonardo, C.G., 2003. Controls on localization and densification of a modern décollement: northern Barbados accretionary prism. Geol. Soc. Am. Bull., 115(3):288-297. doi:10.1130/00167606(2003)115<0288:COLADO>2.0.CO;2

Zoback, M.D., Barton, C.A., Brudy, M., Castillo, D.A., Finkbeiner, T., Grollimund, B.R., Moos, D.B., Peska, P., Ward, C.D., and Wiprut, D.J., 2003. Determination of stress orientation and magnitude in deep wells. Int. J. Rock Mech. Min. Sci., 40(7-8):1049-1076. doi:10.1016/

j.ijrmms.2003.07.001

Publication: 19 July 2013

MS 343343T-101 
Figure F1. A. Location map, showing the eastern coastline of Honshu, bathymetry, Tohoku-oki earthquake epicenter (black star), and location of Expedition 343/343T Site C0019 (red star). Deep Sea Drilling Project (DSDP) Leg 56 Hole 434 and Ocean Drilling Program (ODP) Leg 186 Holes 1150 and 1151 (green circles) are also shown. White arrow $=$ direction of Pacific plate convergence vector. B. Inset map shows orientation of in-line seismic section Line HD33B shown in Figure F2.

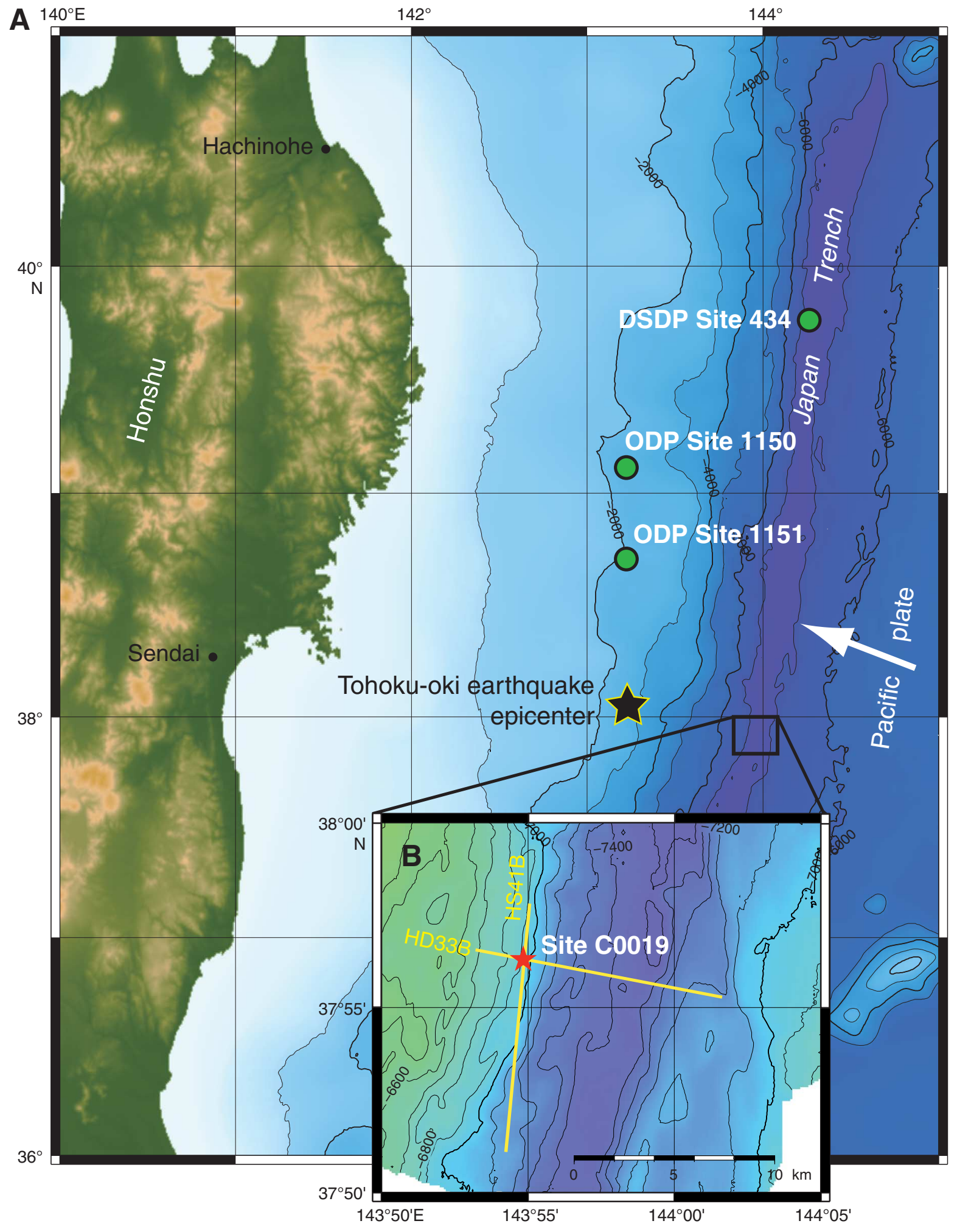


Figure F2. A portion of depth-corrected seismic Line HD33B through Site C0019. The section is partially interpreted, identifying the reflector at the top of the oceanic igneous crust of the incoming Pacific plate, top of the bedded chert, and sedimentary cover. The location of the reflector interpreted as the main décollement between the subducting Pacific plate and the deformed sediments of the overthrust frontal prism are also shown. VE = vertical exaggeration. Modified from Center for Deep Earth Exploration (2012).

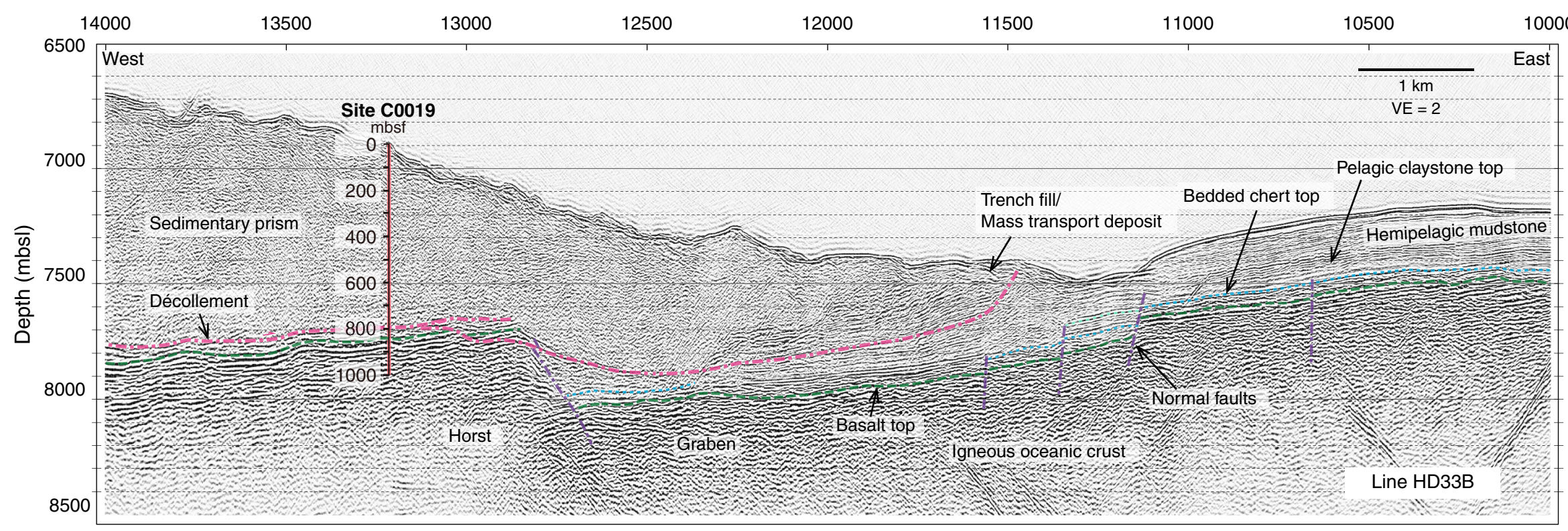


Figure F3. JFAST (Site C0019) site map, showing the location of Holes C0019A-C0019E on a contoured base map of bathymetry.

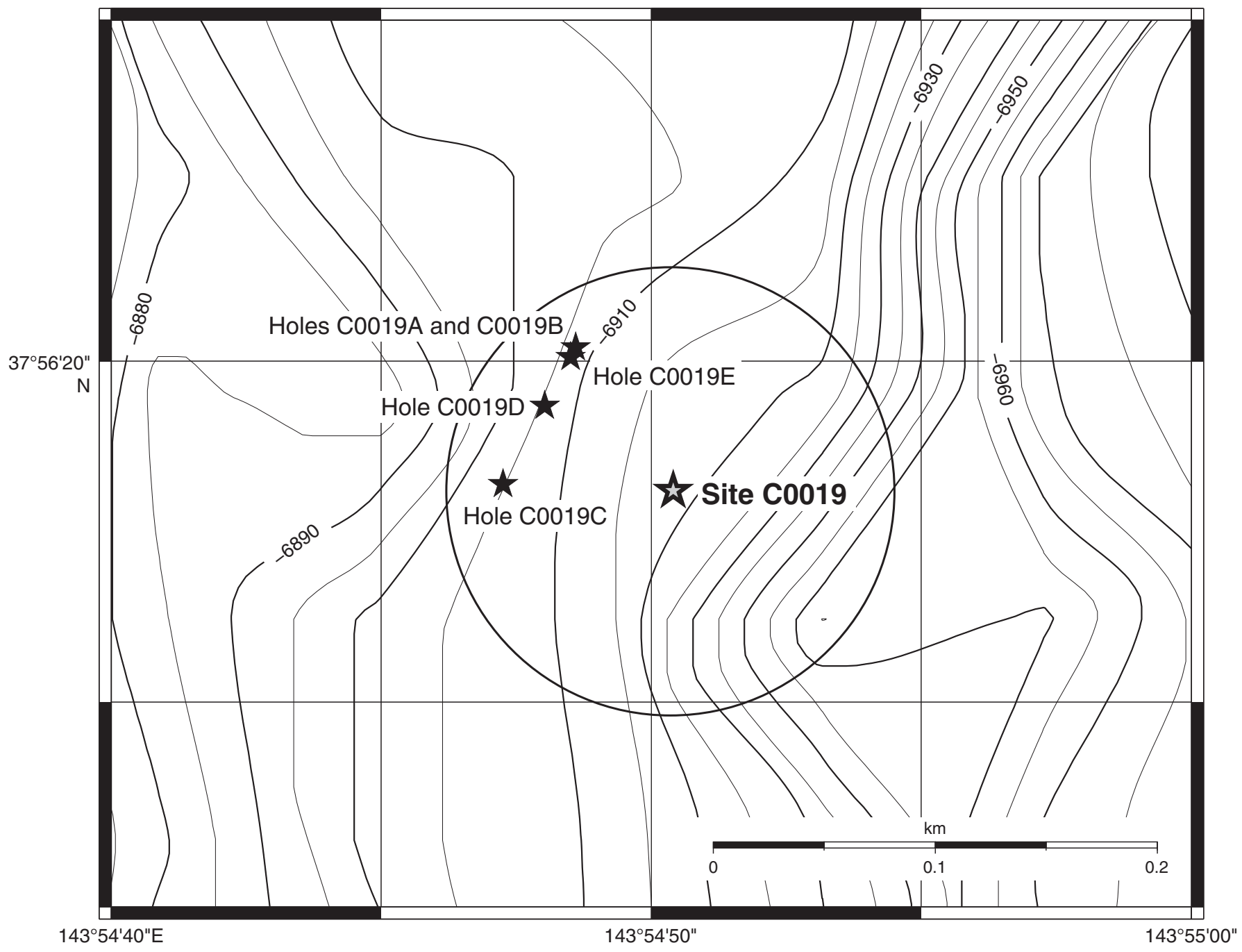


Figure F4. Graphical summary of completed operations in each hole during Expedition 343/343T, showing main log units and schematic section of total depth for Holes C0019A-C0019E. LWD = logging while drilling. MTL = miniature temperature logger.

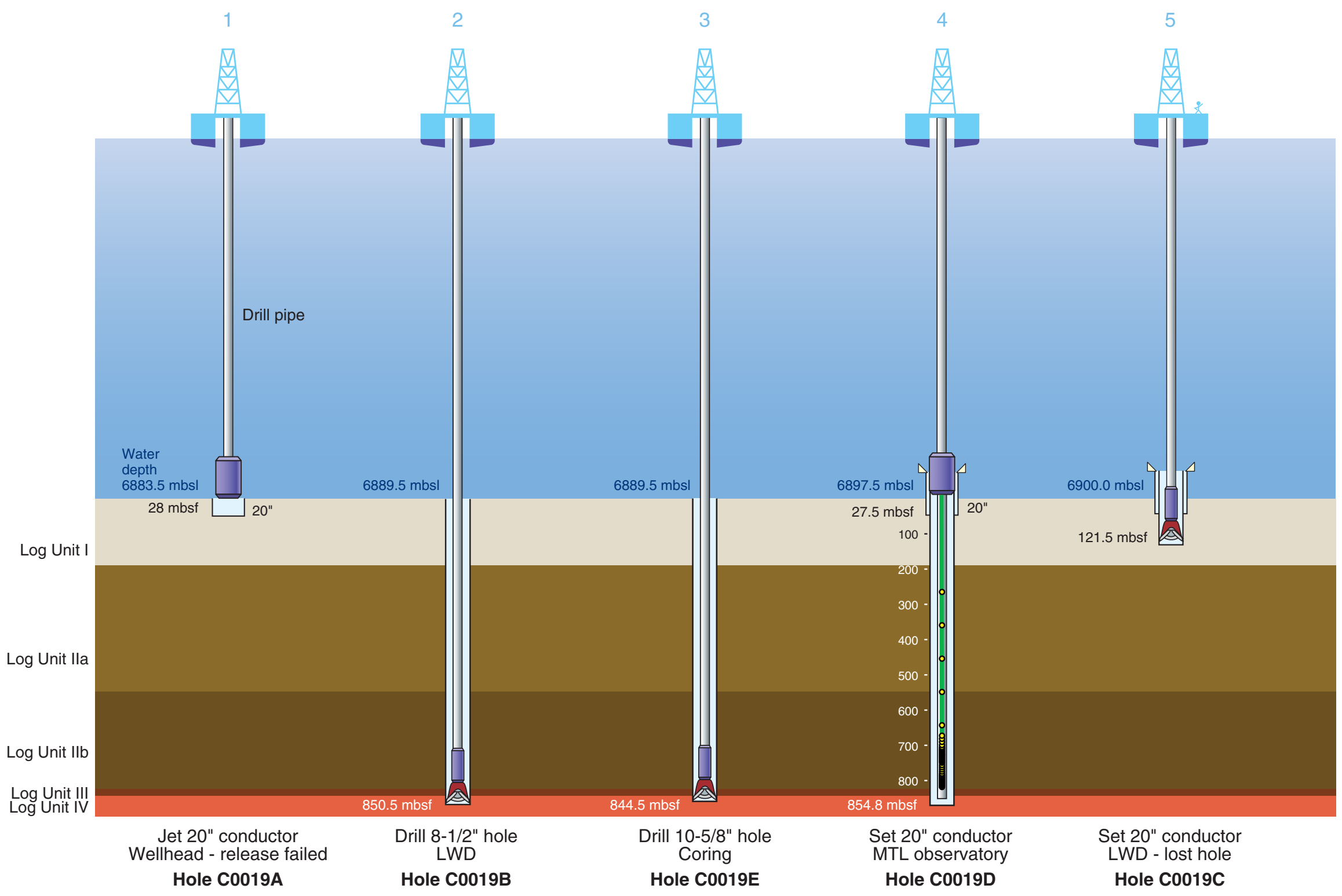


Figure F5. Summary plot of primary geophysical logs as a function of depth, Expedition 343 Hole C0019B. $\mathrm{ECAL}=$ electrical caliper (black line $=$ bit size), $\mathrm{RAB}=$ resistivity-at-the-bit.

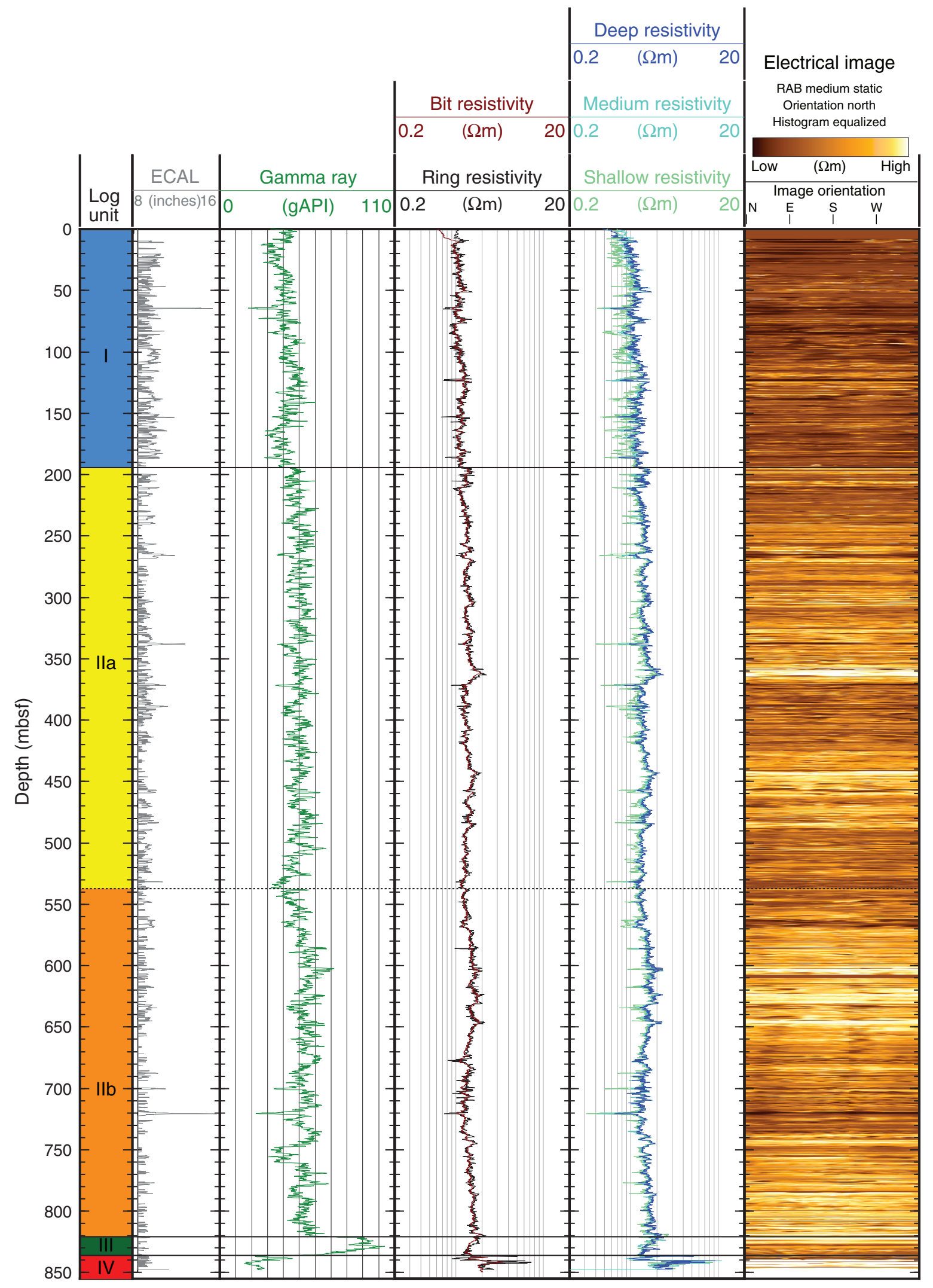


Figure F6. Identification of structural domains in Hole C0019B based on RAB image logs. Bedding and fracture dips identified in image logs are plotted as a function of depth; significant changes in dip distributions constitute the basis for identifying three structural domains. Apparent dips of bedding in the plane of the in-line seismic section through the borehole indicate a predominance of oceanward dipping panels of sediment at intermediate borehole depths, and the structural interpretation illustrates the pronounced disruption of bedding in the vicinity of the 720 and 820 faults. Structural domain: $\mathrm{f}=$ fracture zone.
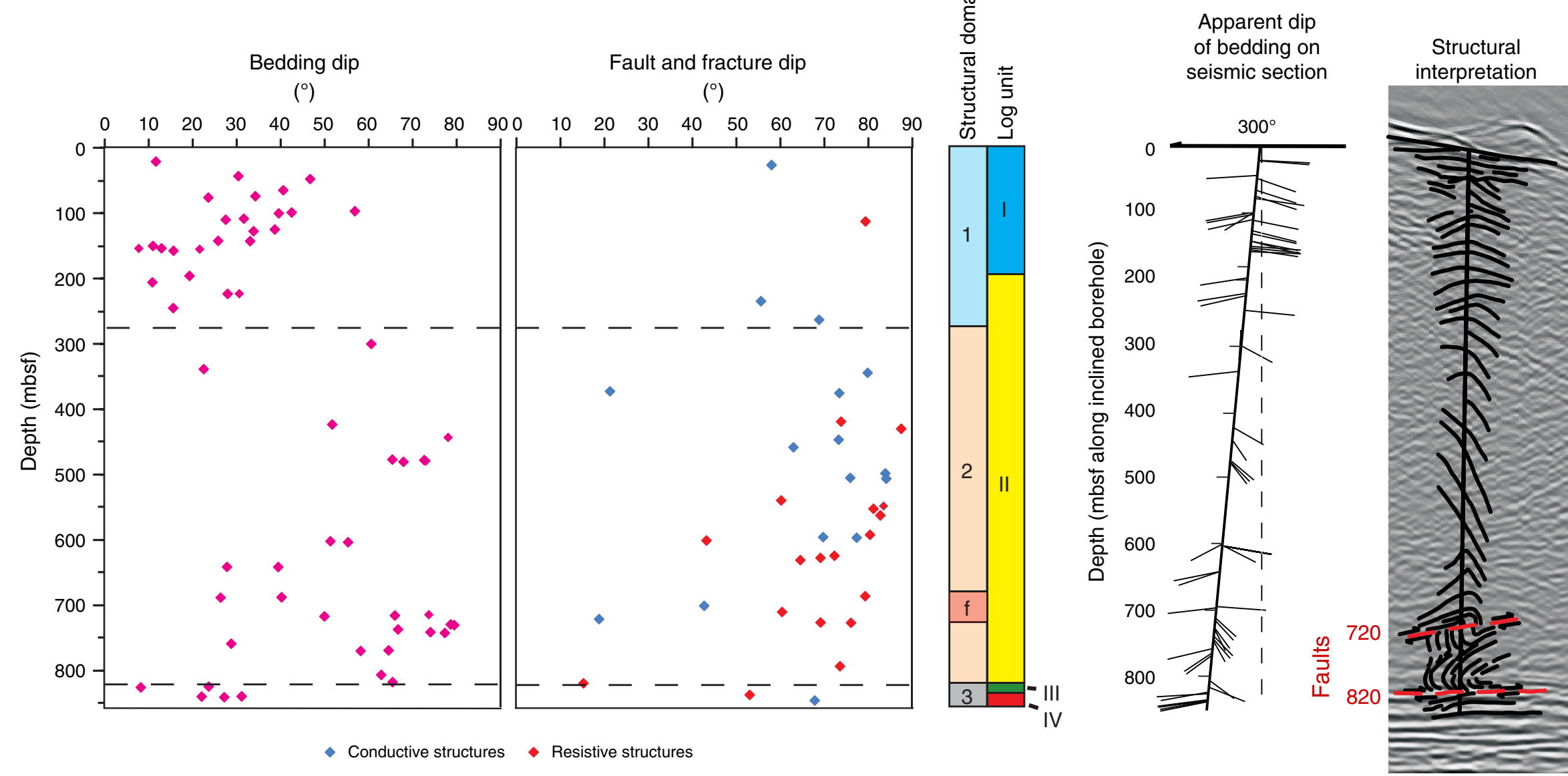
Figure F7. Borehole breakout orientation determined from image logs as a function of depth, Hole C0019B. Breakout azimuths (red circles) are used to identify depth ranges of preferred orientations and general trends in orientations (dashed lines). Within log Subunit IIb, the preferred orientation of breakouts indicates $S_{\text {Hmax }}$ is approximately parallel with the plate convergence direction (see text).

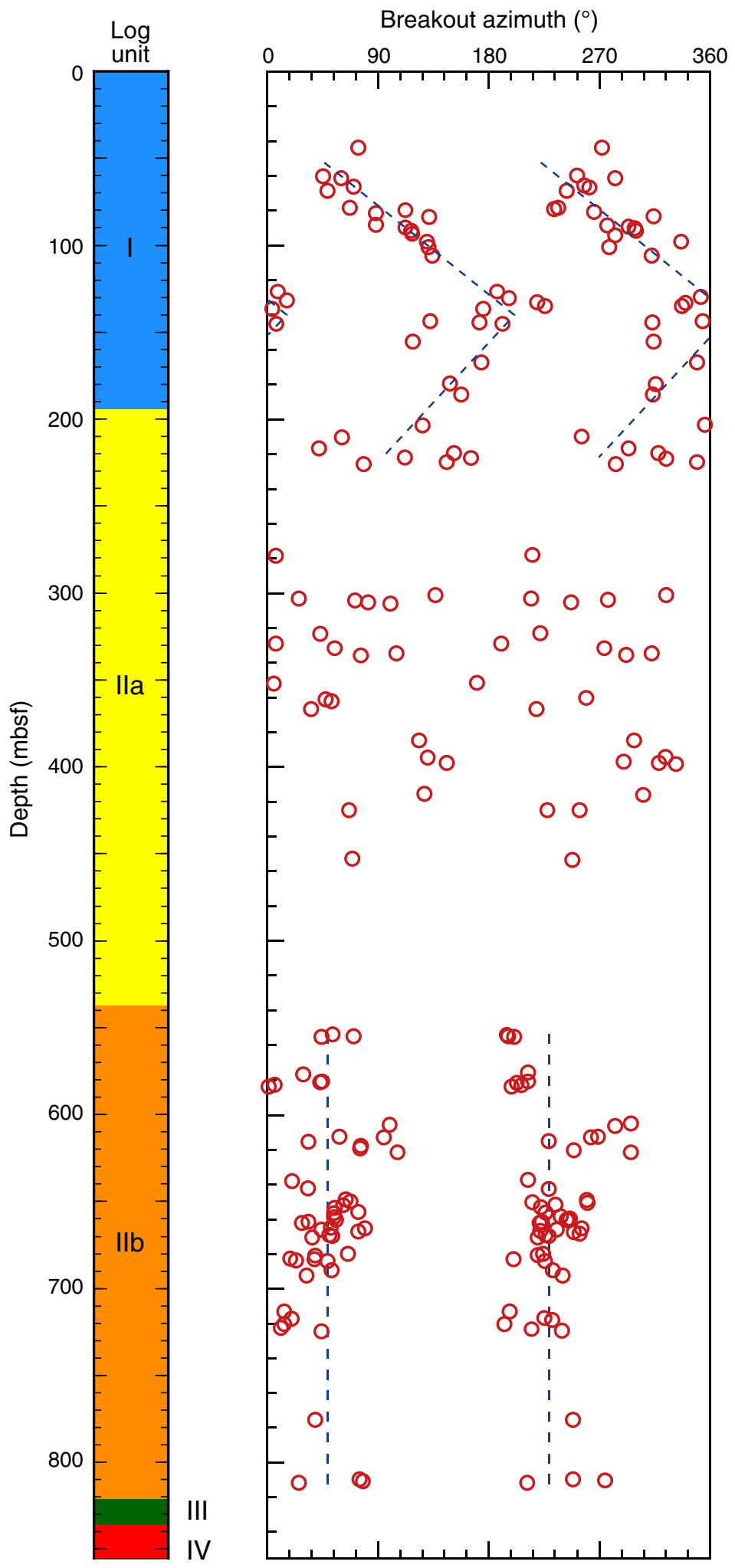


Figure F8. Plot of temperature sensor distribution for the miniature temperature logger (MTL) autonomous observatory deployed in Hole C0019D during Expedition 343T. The density of sensors increases near the 720 and 820 faults in order to accurately define the transient temperature anomaly produced by heating from the Tohoku-oki earthquake. The dense spacing is necessary to resolve the temperature anomaly, which is illustrated for a model temperature distribution in the vicinity of the 820 fault at 1 and $5 \mathrm{y}$ after the earthquake.

\section{MTL positions}

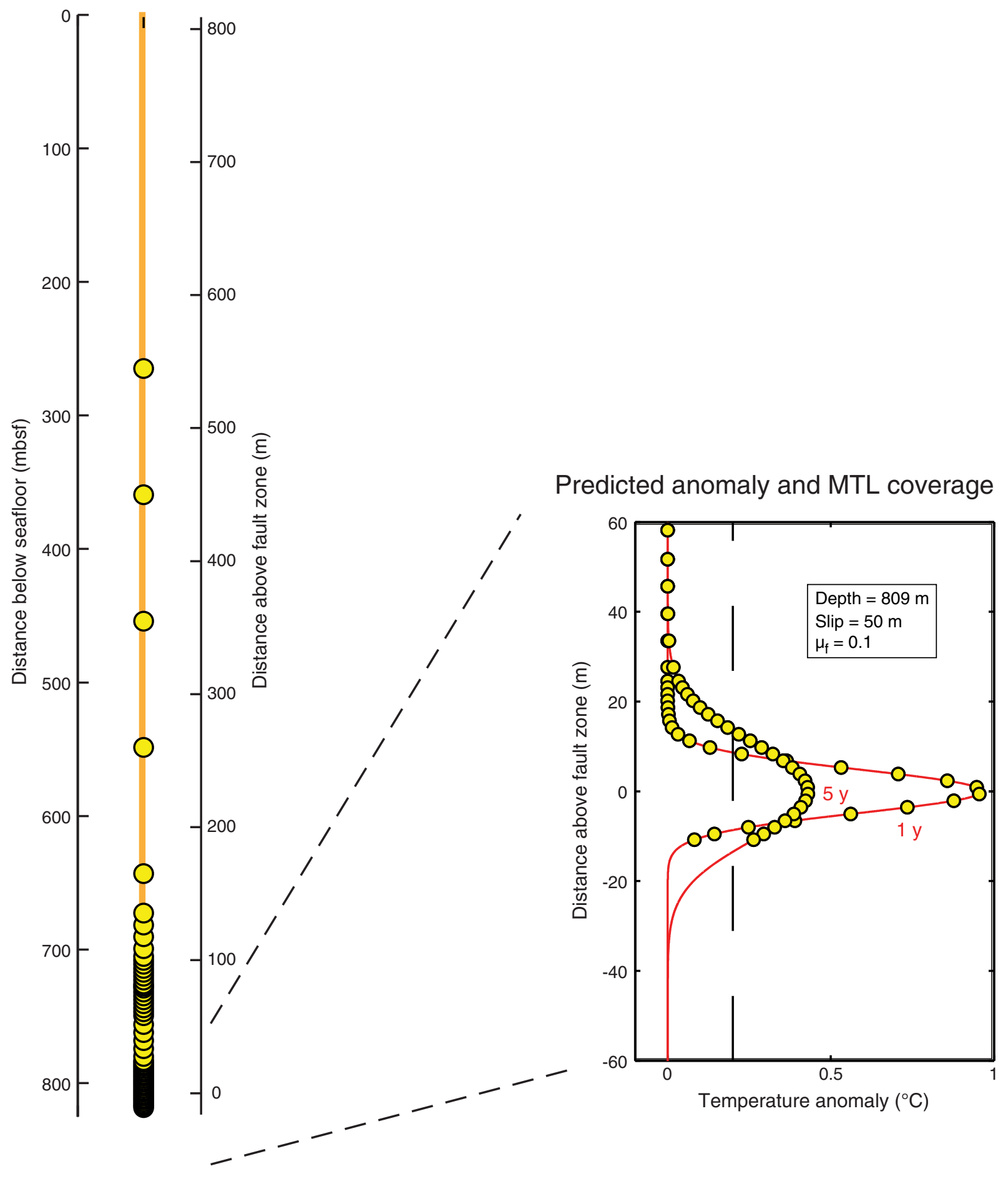


Figure F9. Graphical representation of hole penetration and intervals cored in Expedition 343 Hole C0019E on seismic section Line HD33B. Time limitations demanded only targeted coring, so the majority of cores were taken from the intervals spanning the 720 and 820 faults. Lithology determined on the basis of visual core description (see text) is represented by color in the lithologic column. Seismic Units A, B, and C are shown by brown, yellow, and green shading, respectively. $\mathrm{VE}$ = vertical exaggeration.

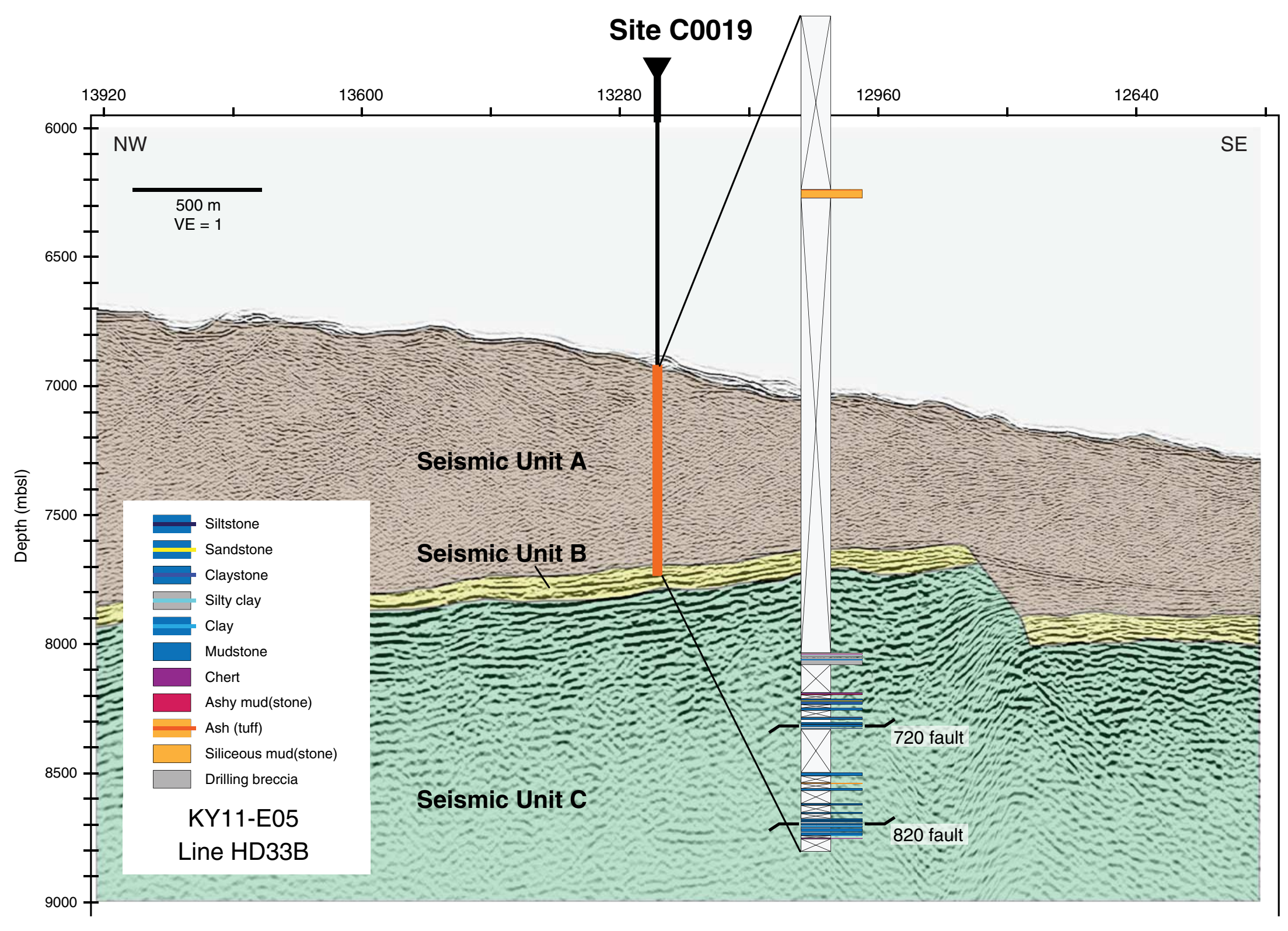


Figure F10. Core-log-seismic data structural summary diagram, Site C0019. Core recovery is shown in black for each core length. Log units are defined using LWD data. Gamma ray: green = LWD gamma ray. Resistivity: dark blue $=$ deep button, turquoise $=$ medium button, light green $=$ shallow button LWD data. Lithologic units are defined from visual core description. $\mathrm{XRF}$ analysis: $\mathrm{K}_{2} \mathrm{O}, \mathrm{Al}_{2} \mathrm{O}$, and $\mathrm{MnO}$ equate to potassium, aluminum and manganese content in core samples, respectively. Structural domains are defined by LWD sinusoid picks on electrical images: $f$ = fracture zone. Dip azimuth: bedding (red open circles) and fracture (blue open circles) orientations picked on LWD resistivity at bit images. Bedding and fracture dip: open circles $=$ LWD data, filled circles $=$ measured on core. Orange transparent overlay boxes show fault zones (720 fault and 820 fault) as defined from visual core description.

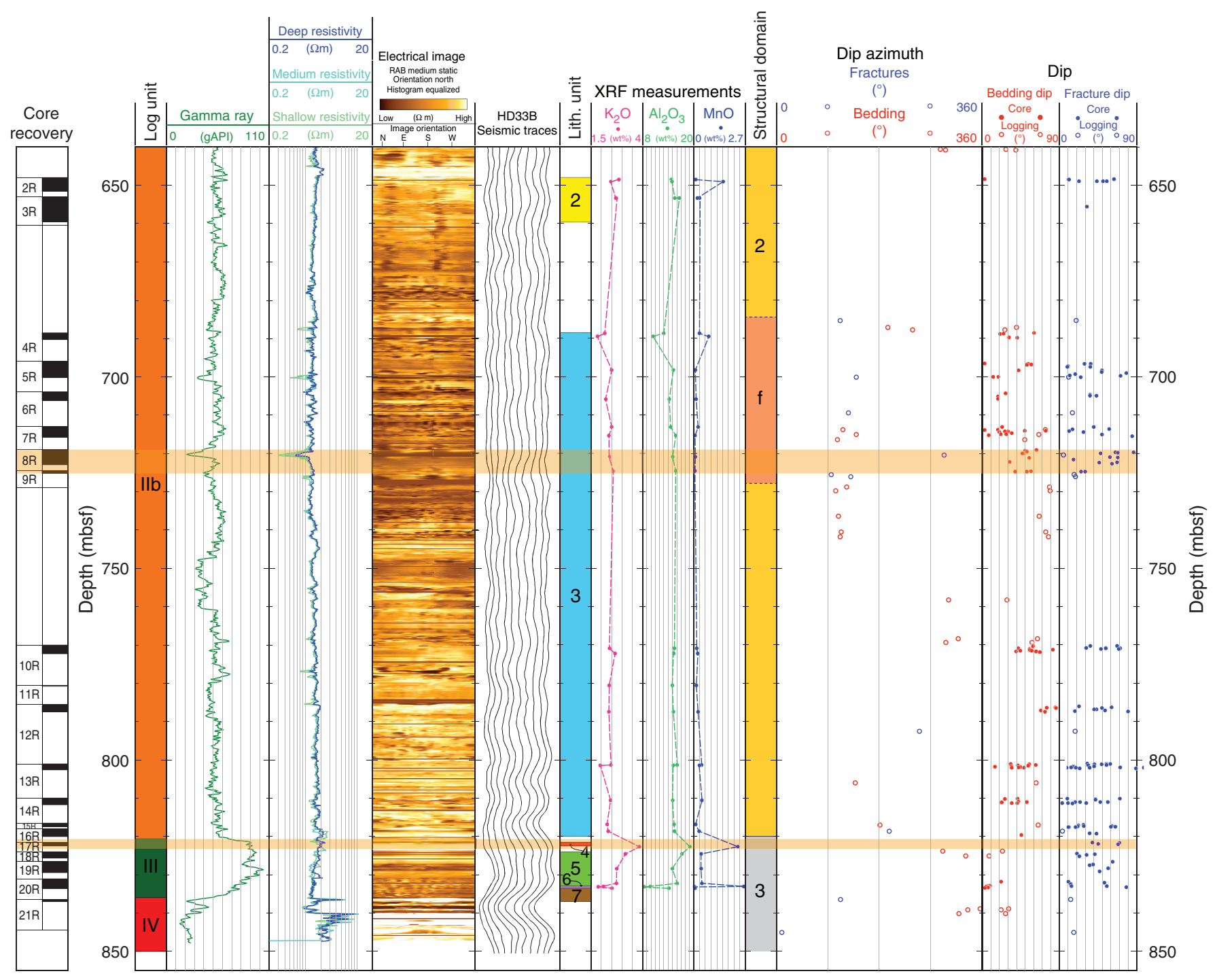


Table T1. Expedition 343/343T coring summary.

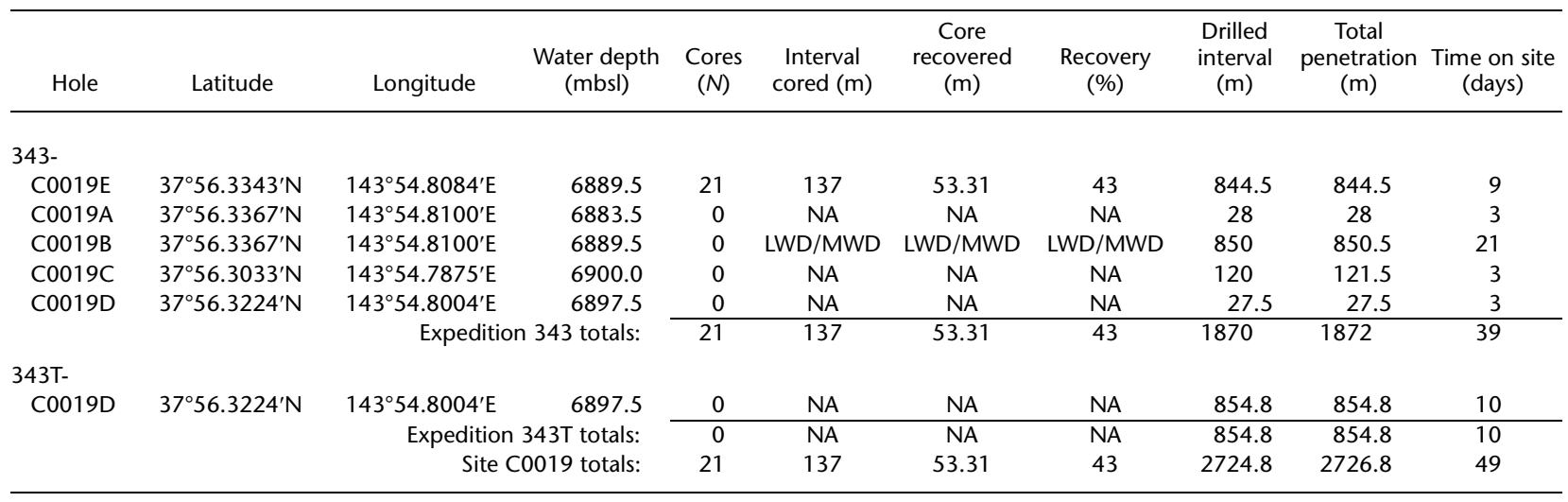

$\mathrm{NA}=$ not applicable. $\mathrm{LWD}=$ logging while drilling, $\mathrm{MWD}=$ measurement while drilling . 